\title{
A Novel and Highly Regioselective Synthesis of New Carbamoylcarboxylic Acids from Dianhydrides
}

\author{
Adrián Ochoa-Terán, ${ }^{1}$ Jesús Estrada-Manjarrez, ${ }^{2}$ Marisela Martínez-Quiroz, ${ }^{1}$ \\ Marco A. Landey-Álvarez, ${ }^{1}$ Eleazar Alcántar Zavala, ${ }^{3}$ Georgina Pina-Luis, ${ }^{1}$ \\ Hisila Santacruz Ortega, ${ }^{4}$ Luis Enrique Gómez-Pineda, ${ }^{1}$ José-Zeferino Ramírez, ${ }^{4}$ \\ Daniel Chávez, ${ }^{1}$ Julio Montes Ávila, ${ }^{3}$ Victoria Labastida-Galván, ${ }^{5}$ and Mario Ordoñez ${ }^{5}$ \\ ${ }^{1}$ Centro de Graduados e Investigación, Instituto Tecnológico de Tijuana, 22510 Tijuana, BC, Mexico \\ ${ }^{2}$ Departamento de Ingeniería Bioquímica, Instituto Tecnológico de Culiacán, 80220 Culiacán, SIN, Mexico \\ ${ }^{3}$ Facultad de Ciencias Químico Biológicas, Universidad Autónoma de Sinaloa, 80010 Culiacán, SIN, Mexico \\ ${ }^{4}$ Departamento de Polímeros y Materiales, Universidad de Sonora, 83000 Hermosillo, SON, Mexico \\ ${ }^{5}$ Centro de Investigaciones Químicas, Universidad Autónoma del Estado de Morelos, 62209 Cuernavaca, MOR, Mexico
}

Correspondence should be addressed to Adrián Ochoa-Terán; ochoa@tectijuana.mx

Received 6 November 2013; Accepted 26 November 2013; Published 6 January 2014

Academic Editors: C. Lopez-Leonardo, A. Marra, A. Sacchetti, and A. Sirit

Copyright (C) 2014 Adrián Ochoa-Terán et al. This is an open access article distributed under the Creative Commons Attribution License, which permits unrestricted use, distribution, and reproduction in any medium, provided the original work is properly cited.

A regioselective synthesis has been developed for the preparation of a series of $N, N^{\prime}$-disubstituted $4,4^{\prime}$-carbonylbis(carbamoyl-

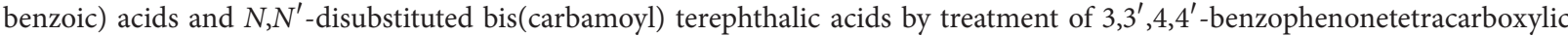
dianhydride (1) and 1,2,4,5-benzenetetracarboxylic dianhydride (2) with arylalkyl primary amines (A-N). The carbamoylcarboxylic acid derivatives were synthesized with good yield and high purity. The specific reaction conditions were established to obtain carbamoyl and carboxylic acid functionalities over the thermodynamically most favored imide group. Products derived from both anhydrides $\mathbf{1}$ and $\mathbf{2}$ were isolated as pure regioisomeric compounds under innovative experimental conditions. The chemo- and regioselectivity of products derived from dianhydrides were determined by NMR spectroscopy and confirmed by density functional theory (DFT). All products were characterized by NMR, FTIR, and MS.

\section{Introduction}

Some $N$-aryl 2-carbamoylbenzoic acids, commonly known as phthalamic acids, are auxin transport inhibitors in plants [1-4]. The activity of these phytotropins is directly related to the carboxylic acid group attached to an aromatic ring in the ortho position of a second aromatic ring through a conjugated or a planar system of atoms. The spatial requirement for a high activity is the specific distance between the two aromatic ring centers $(7.3 \AA)$. Other biological effects of this molecule in plants include the ability to inhibit the polar transport of auxins, to abolish the apical dominance effect, and to prevent the geo- and phototropic response. In particular the N-1-naphthyl-2-carbamoylbenzoic acid (NACBA) is known as a potent inhibitor of auxins transport and geotropic curvature. It also has the capacity to bind to fractions containing plasma membrane vesicles from maize coleoptiles.

Recently, the synthesis of $N$-aryl-2-carbamoylbenzoic acids under microwave assisted conditions from phthalic anhydride and aryl or heterocyclic amines in the absence of solvent with yields 51-99\% has been reported [5]. Significant research findings show that these $N$-arylphthalamic acids induce hyperlipidemia in Swiss white mice and also an increase in body weight of the animals, in contrast with the hypolipidemic activity showed by their phthalimide analogues [6].

In addition, 2-carbamoylbenzoic acids and structurally related compounds have shown attractive pharmaceutical and agricultural applications as novel anti-inflammatory, immunomodulatory, antiproliferatory, antithrombotic, and 
<smiles>NC(=O)c1ccccc1C(=O)O</smiles>

ACBA<smiles>O=C(Nc1ccccc1C(=O)O)c1ccccc1</smiles>

PACBA

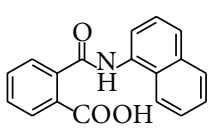

NACBA

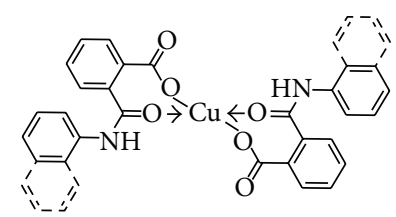

FIGURE 1: Carbamoybenzoic acids as monotopic ligands in organometallic complexes.

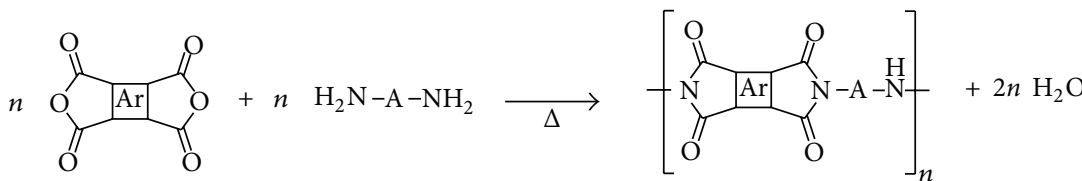<smiles>Cc1ccc(C(=O)c2ccc(C)c(C)c2)cc1C</smiles><smiles>Cc1ccc(Oc2ccc(C)c(C)c2)cc1C</smiles><smiles>Cc1ccc(C(C)(C)c2ccc(C)c(C)c2)cc1C</smiles>

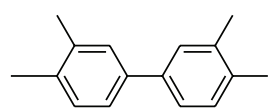<smiles>Cc1ccc(C)c2c(C)ccc(C)c12</smiles><smiles>Cc1cc(C)c(C)cc1C</smiles>

A = aliphatic, heteroaliphatic, aromatic, and heteroaromatic

Scheme 1: Synthesis of polyimides from aromatic dianhydrides.<smiles>CC1=CC(=O)C2C3C(=O)OC(=O)C3C12</smiles><smiles>Nc1ccccc1</smiles><smiles>[R]NC(=O)C1=C(C(=O)O)C(C(=O)O)C1C(=O)N[R]</smiles>
and/or RHN<smiles>[R]NC(=O)C1=C(C(=O)N[R1])C(C(=O)O)C1C(=O)O</smiles><smiles>[R]N1C(=O)C2C(C1=O)C1C(=O)N([R])C(=O)C21</smiles>

SCHEME 2: Synthesis of diimides from aromatic dianhydrides.

antituberculosis agents, as well as plant growth regulators [7-10]. Recently, the synthesis of compounds containing a carbamoylbenzoic acid functionality, showing BMP 2 stimulation and osteoblast differentiation has been reported [11]. As well, these compounds have industrial applications as surfactants, emulsifiers, and conditioning agents in shampoos, and as part of antiperspirant formulations, among others $[12,13]$. However, to the best of our knowledge, there are not reports in the literature regarding the synthesis, properties, or applications of carbamoylbenzoic acids bearing $N$-alkyl or $N$-alkylaryl substituents.

Lingaiah and coworkers have prepared organometallic complexes using 2-carbamoylbenzoic acid (ACBA), $N$ phenyl-2-carbamoylbenzoic acid (PACBA), and N-naphthyl2-carbamoylbenzoic (NACBA) as monotopic ligands with $\mathrm{Cu}^{2+}$ (Figure 1) [14]. They found a stoichiometric 1:2 metalligand ratio in these complexes. In addition, they demonstrated that the interaction between ligands and metallic center is through an ionic metal-heteroatom bond with the carboxylate group and a coordinated bond with the amide carbonyl group. However, they have not been reported catalytic applications of these organometallic complexes.
Traditionally, aromatic dianhydrides are used as starting materials in the synthesis of water soluble polymers as polyimides (Scheme 1) [15-21]. These compounds are distinguished as high performance polymers due to their excellent chemical, mechanical, and dielectric resistance in a broad temperature interval. In the aerospace and electronic industry, polyimides are mainly used to form films and moldings. Other applications as adhesives, gas separation membranes, composite matrices, coatings, and foams are rapidly increasing [22-25].

Aromatic dianhydrides, especially naphthalene and benzophenone dianhydrides, are commonly used in the synthesis of aromatic diimide monomers. These compounds have been extensively studied due to their interesting physicochemical properties and their applications [26-29]. However, the bis(carbamoylcarboxylic) acid intermediates have not received much attention due to the difficulty to obtain them in a chemoselective way and with high purity (Scheme 2) [30]. As above mentioned, these molecules are potentially bioactive compounds and ligands in organometallics and materials chemistry. 


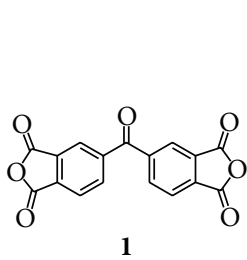

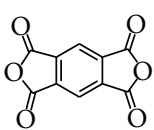

2<smiles>Nc1ccncc1</smiles><smiles>NCc1ccccn1</smiles><smiles>NCc1cccnc1</smiles>
C<smiles>NCc1ccccc1</smiles><smiles>NCc1c(F)cccc1F</smiles><smiles>Nc1ccccc1Cl</smiles>

H<smiles>COc1ccccc1CCN</smiles>

$\mathbf{M}$

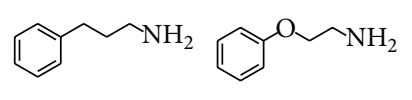

$\mathbf{L}$<smiles>NCc1cccc2ccccc12</smiles>

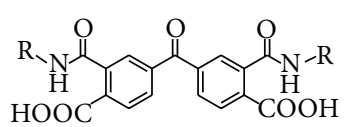

$3(\mathrm{~A}-\mathrm{N})$<smiles>[R]NC(=O)c1cc(C(=O)O)c(C(=O)N[R])cc1C(=O)O</smiles>

$6(\mathrm{~A}-\mathrm{N})$

Figure 2: Substrates used for the synthesis of bis(carbamoylcarboxylic) acids.

In this work, specific experimental conditions were implemented for the chemo- and regioselective synthesis and achievement of a series of aromatic bis(carbamoylcarboxylic) acids derived from benzophenone and benzene dianhydrides with good yields.

\section{Results and Discussion}

2.1. Synthesis and Characterization. The synthesis of bis(carbamoylcarboxylic) acids was developed using two different core dianhydride substrates (Figure 2), such as 3,3',4,4' -benzophenonetetracarboxylic dianhydride (1) (formally two phthalic anhydrides linked by a carbonyl group) and 1,2,4,5benzenetetracarboxylic dianhydride (2) (two anhydride groups with a benzene ring bridge). The selected primary amines contain phenyl, pyridyl, or naphthyl aromatics rings, attached directly to the amine group or separated by alkyl or heteroalkyl chains. Also, fluorine, chlorine, and methoxy substituents are present in some aromatic rings. The combination of different core structures and substituents leads to obtaining product diversity with a wide potential range of chemical, spectroscopic, and biological properties.

It is well known, that the synthesis of this type of compounds occurs by a nucleophilic attack of amine group to the anhydride ring to obtain the corresponding bis(carbamoylbenzoic) or bis(carbamoyl) terephthalic acid structure. Thus, reactions were performed in THF, Toluene, or $\mathrm{EtOH}$ as solvent depending of reactant solubility. Most of the products were isolated by filtration and suspended into a 5\% $\mathrm{HCl}$ aqueous solution to eliminate the amine in excess.

The 4,4'-carbonyl bis(2-carbamoylbenzoic) acids 3(AN) were obtained in yields of 60 to $>98 \%$ and high purity (Table 1). In their FTIR spectra, was observed the following: at $3390-3100 \mathrm{~cm}^{-1}$ the vibration corresponding to $\mathrm{N}-\mathrm{H}$ and at
$1670-1630 \mathrm{~cm}^{-1}$ the vibrations corresponding to the ketone, carboxylic acid, and amide carbonyl stretching. The signal corresponding to the amide hydrogen was not observable at low field in ${ }^{1} \mathrm{H}$ NMR spectra, but a broad singlet at 7.60 to $4.00 \mathrm{ppm}$ that disappeared when a $\mathrm{D}_{2} \mathrm{O}$ drop was added was assigned to this hydrogen. The HDO formed by the exchange of the $\mathrm{NH}$ hydrogen appeared at 4.05 to $3.65 \mathrm{ppm}$ (see Supplementary Material available online at http://dx.doi.org/10.1155/2014/725981). There are signals belonging to the aromatic substituent on the amide group and three more at 8.54 to $8.06 \mathrm{ppm}, 8.34$ to $7.95 \mathrm{ppm}$, and 7.87 to $6.70 \mathrm{ppm}$ for aromatic benzophenone core. In the ${ }^{13} \mathrm{C}$ NMR spectra, the signals at 199.8 to $193.4 \mathrm{ppm}, 168.3$ to $167.1 \mathrm{ppm}$, and 168.1 to $167.0 \mathrm{ppm}$ corresponding to ketone, carboxylic, and amide carbonyl groups are observable. The quasimolecular ions were not detected in ESIMS on neither negative nor positive modes. In EIMS adducts $\mathrm{M}^{+}-2 \mathrm{H}_{2} \mathrm{O}$ that correspond to the diimide analogs formed by dehydration of two carbamoylcarboxylic acids units were detected.

The bis(carbamoyl) terephthalic acids $\mathbf{6}(\mathbf{A}-\mathbf{N})$ were obtained in low to moderate yields (12 to $48 \%$ ) when the reaction was carried out at room temperature in THF or $\mathrm{EtOH}$. But when the mixture was refluxed in THF or Toluene the yields increase considerably (Table 1). All products were separated from the reaction mixture by filtration and washed with an aqueous $\mathrm{HCl}$ solution and obtained in high purity. When the filtrate was evaporated a solid product identified as the diimide analog was obtained in very low amounts.

Also, in their FTIR spectra was observed the following: at $3390-3100 \mathrm{~cm}^{-1}$ the vibration corresponding to $\mathrm{N}-\mathrm{H}$ and at $1670-1630 \mathrm{~cm}^{-1}$ the vibrations corresponding to the carboxylic acid and amide carbonyl stretching. The ${ }^{1} \mathrm{H}$ NMR spectra showed one signal for the amide group hydrogen as a triplet or singlet between 10.60 and $8.53 \mathrm{ppm}$. A singlet 
TABLE 1: Yields for bis(carbamoylcarboxylic) acids.

\begin{tabular}{lcc}
\hline Amine & \multicolumn{3}{c}{ Products } & $\mathbf{6}$ \\
\hline $\mathbf{A}$ & 92 & $>98$ \\
$\mathbf{B}$ & 60 & 68 \\
$\mathbf{C}$ & 63 & 89 \\
$\mathbf{D}$ & $>98$ & 82 \\
$\mathbf{E}$ & 83 & 63 \\
$\mathbf{F}$ & 85 & 90 \\
$\mathbf{G}$ & $>98$ & 80 \\
$\mathbf{H}$ & $>98$ & 86 \\
$\mathbf{I}$ & $>98$ & $>98$ \\
$\mathbf{J}$ & 96 & 82 \\
$\mathbf{K}$ & 63 & 86 \\
$\mathbf{L}$ & 74 & 71 \\
$\mathbf{M}$ & $>98$ & 84 \\
$\mathbf{N}$ & 98 & 98 \\
\hline
\end{tabular}

signal between 8.91 and $7.65 \mathrm{ppm}$ that integrates for the two hydrogens at the aromatic core structure was found. In the ${ }^{13} \mathrm{C}$ NMR spectra, two signals at 171.5 to $166.6 \mathrm{ppm}$ and 168.1 to 165.8 ppm corresponding to carboxylic and amide carbonyl groups are observable. In EIMS adducts $\mathrm{M}^{+}-2 \mathrm{H}_{2} \mathrm{O}$ that correspond to the diimide analogs formed by dehydration of two carbamoylcarboxylic acids units were detected.

2.2. Chemo- and Regioselectivity in the Ring-Opening of Dianhydrides. During the reaction of benzophenonetetracarboxylic dianhydride (1) with primary amines, it is possible to obtain three regioisomers (Scheme 3). Regioisomers 3(A$\mathrm{N})$ and $4(\mathrm{~A}-\mathrm{N})$ have symmetric structures and regioisomers $\mathbf{5}(\mathbf{A}-\mathbf{N})$ are nonsymmetrical. The simplicity of the NMR signals showed that only one of the possible regioisomers was obtained. Based on the low signals number, the nonsymmetrical compounds $\mathbf{5}(\mathrm{A}-\mathrm{N})$ were discarded.

To elucidate which regioisomer was favored under these conditions, an NMR titration of the 1-naphthylmethyl derivative $(3 \mathbf{N})$ was consummated using $\mathrm{Ca}^{2+}$ to form a complex in solution. As shown in Figure 3, the three signals of benzophenone core $(\mathbf{a}, \mathbf{b}$, and $\mathbf{c})$ were affected in their chemical shift and shape when one equivalent of $\mathrm{Ca}^{2+}$ was added, indicating coordination between the molecule and the metal ion through the amide carbonyl and the ionic bond with the carboxylate group [14]. In the complex this part of the molecule becomes more rigid and relaxing times of $\mathbf{a}, \mathbf{b}$, and c hydrogens increase until the same level of acquisition time of the NMR instrument resulting in the broadening of the signals near to the coordination site [31-34]. Here the signal with higher broadening was the doublet at $8.30 \mathrm{ppm}$ (signal b) which is expected to be more affected by the coordination in regioisomer 3 than in $\mathbf{4}$, when carboxylate group coordinates with $\mathrm{Ca}^{2+}$. From this experimental result, regioisomers 4 were discarded.

Meanwhile, as depicted in Scheme 4, 1,2,4,5-benzenetetracarboxylic dianhydride (2) was reacted with a series of primary amines and was expected to obtain a mixture of two regioisomeric products. If the amine attacks the carbonyl groups at opposite side of molecule, antisymmetric terephthalic acids $\mathbf{6}(\mathbf{A}-\mathbf{N})$ could be obtained, while if the amine reacts with the carbonyl groups on the same side, symmetric terephthalic acids $7(\mathbf{A}-\mathbf{N})$ would be expected.

The ${ }^{1} \mathrm{H}$ NMR spectra showed one signal for the amide group hydrogen as a triplet or singlet indicating the amide and carboxylic acid functionalities in these molecules. Only one singlet signal that integrates for the two hydrogens at the aromatic core structure was found indicating that the two hydrogens have identical chemical environment, which can be possible only in the antisymmetric regioisomers $\mathbf{6}(\mathrm{A}-\mathrm{N})$ because both hydrogens are in ortho position to a carboxylic and amide group, while significant differences should be present in the symmetric regioisomer due to one hydrogen is in ortho position to two amide groups and the other one is in ortho position to two carboxylic acids. When reaction was performed in EtOH as solvent at room temperature, some compounds as $6 \mathbf{F} / 7 \mathbf{F}$ were isolated as a regioisomeric mixture. In the ${ }^{1} \mathrm{H}$ NMR spectra of this sample two triplet appeared at 10.72 and $10.55 \mathrm{ppm}$ assigned to amide hydrogen. But more importantly, a singlet signal at $7.88 \mathrm{ppm}$ corresponding to the two aromatic core hydrogens of $6 \mathrm{~F}$ (antisymmetric regioisomer) and two singlet signals at $8.04 \mathrm{ppm}$ and $7.73 \mathrm{ppm}$ assigned to each aromatic core hydrogen of $7 \mathbf{F}$ (symmetric regioisomer) were found. In products were the aromatic substituent is attached directly to the amide group, as compounds $6 \mathrm{E} / 7 \mathrm{E}$ and $6 \mathrm{M} / 7 \mathrm{M}$, the NMR spectra shown both regioisomers perfectly identified because is present a singlet that corresponds to the two aromatic hydrogens of benzene core in products 6 and two singlet signals corresponding to each hydrogen of the benzene core in products 7. Additionally, there are singlet signals at low field for the $\mathrm{NH}$ amide with different chemical shift (see Supplementary Material).

2.3. Computational Modeling in the Ring-Opening of Dianhydrides. As is well documented, chemical reactivity of a molecule can be described by Density Functional Theory (DFT) method, and the local quantity or Fukui function provides information about the reactive behavior of atoms forming a molecule. The Fukui function is defined as

$$
f_{k}^{+}=q_{k}(N+1)-q_{k}(k)
$$

where $f_{k}^{+}$represents the measure reactivity toward a nucleophilic reagent and $q_{k}$ is the electronic population of atom $k$ in the molecule [35]. The electronic population is evaluated in terms of the electrostatic potential (ESP) single point calculation [36]. A high value of $f_{k}^{+}$indicates that atom $k$ is highly reactive when compared to other atoms in the molecule. First, the geometry of dianhydride 1 was optimized and confirmed through the frequency calculation. Figure 4 shows $f_{k}^{+}$calculated for atoms involved in the ring opening. Based on Fukui values, the anhydride carbonyls attached at 3 and $3^{\prime}$ positions have higher probability for a nucleophilic attack. Therefore, we can assume that regioisomers $3(\mathbf{A}-\mathbf{N})$ 


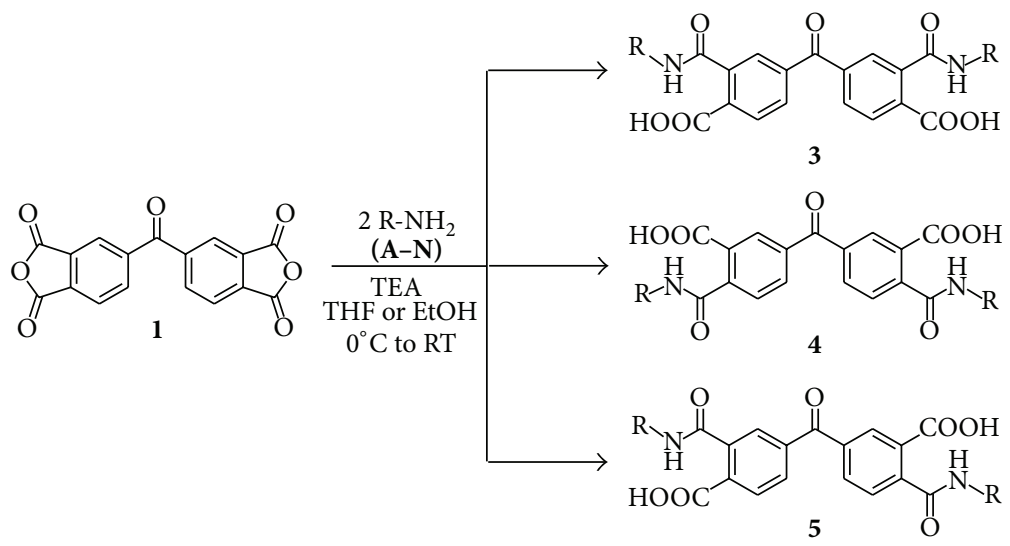

Scheme 3: Plausible regioisomers obtained on the synthesis of $4,4^{\prime}$-carbonyl bis(2-carbamoylbenzoic) acids.<smiles>[R]NC(=O)c1ccc(C(=O)c2ccc(C(=O)O[Te](C)(OC)OC(=O)c3ccc(C(=O)c4ccc(C(=O)O)c(C(=O)N[R])c4)cc3C(=O)N[R])c(C(=O)N[R])c2)cc1C(=O)O</smiles>

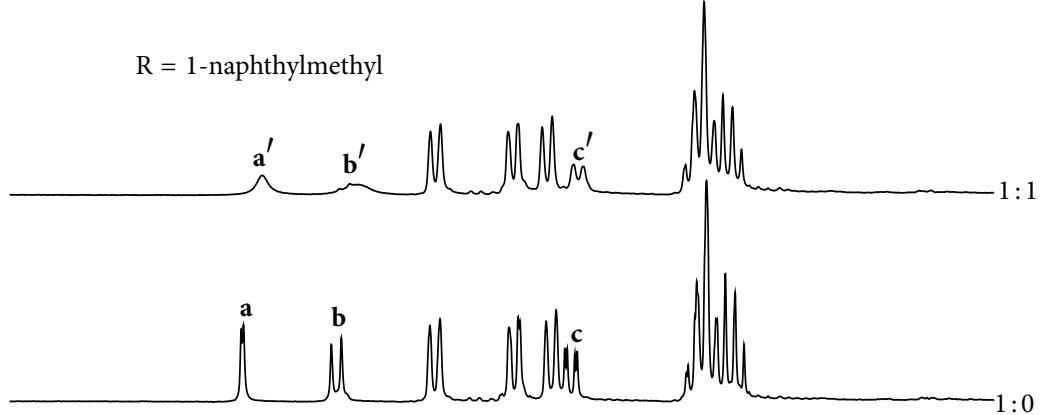

FIgURE 3: NMR titration of $3 \mathrm{~N}$ with $\mathrm{Ca}^{2+}$ ions in DMSO- $d_{6}$.

are favored in the reaction with amines. This result is remarkably in agreement with the NMR titration.

The energy diagram for the reaction pathway showed that benzophenone dianhydride has high energy, and is therefore a highly reactive compound (Figure 5). Conversion to the bis(carbamoylcarboxylic) functionality is an exothermic process. But it was more important to find that formation of diimide analog II is even more exothermic, which means that at experimental conditions used in the reaction, formation of diimide analogs are favorable too. However, the insolubility of products in the reaction media allowed isolating them in good yields.

As well as dianhydride $\mathbf{1}$, Fukui values were calculated in dianhydride 2 finding that antisymmetric carbonyls are the most suitable sites for nucleophilic attack (Figure 6).

Moreover, Fukui functions of monocarbamoylcarboxylic acid derived from 2-methoxybenzylamine was calculated. In Figure 7 the structures of the two most stable geometries for this intermediate are shown. In the first one, Fukui function defines the same side carbonyl as the most suitable site for the nucleophilic attack; but in the second, where an intramolecular hydrogen bond stabilizes the molecule in a $2.3 \mathrm{kcal} / \mathrm{mol}$, Fukui function defines the opposite side carbonyl as the most favored for the reaction with the amine. Intramolecular hydrogen bond between carboxylic hydrogen and amide carbonyl determinate the geometry as well as the reactivity of this intermediate.

This result is also in agreement with regioselectivity observed in different solvents. Nonprotic solvent as THF or Toluene favors the intramolecular hydrogen bond and as consequence the antisymmetric regioisomer formation. A protic solvent as $\mathrm{EtOH}$ competes in the hydrogen bond formation modifying the molecule geometry and reactivity.

The energy diagram for the reaction pathway is in agreement with the experimental conditions that favor the observed chemoselectivity and high yields. The synthesis of monocarbamoylcarboxylic intermediate III is an exothermic process as well as the opening of the second anhydride ring. On the contrary diimide analog IV formation is an endothermic process; therefore the heating in the reaction 


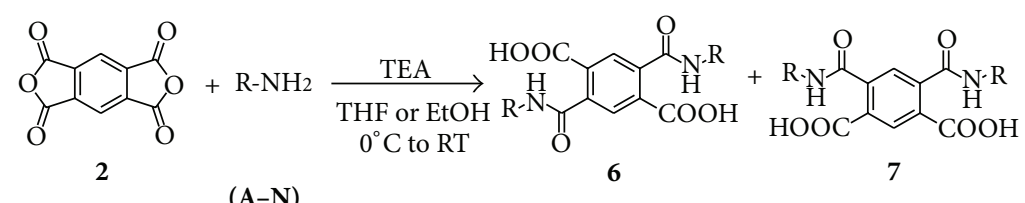

SCHEME 4: Plausible regioisomers obtained on the synthesis of bis(carbamoyl) terephthalic acids.

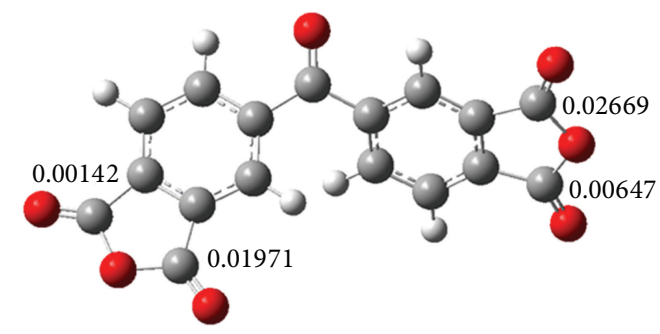

Figure 4: The Fukui function calculated for atoms involved in the ring-opening of dianhydride 1 .

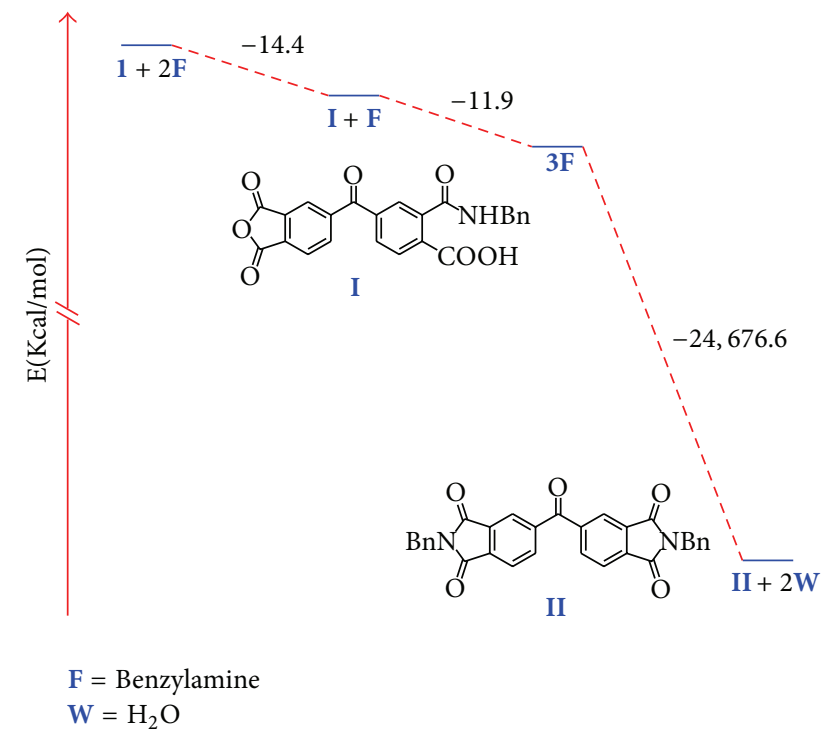

FIGURE 5: Energy diagram for the reaction pathway of dianhydride 1 and benzylamine.

favors diimide formation only in small amounts (Figure 8). Nevertheless, bis(carbamoyl) terephthalic acids are obtained in good yields due to their insolubility in the reaction media.

\section{Conclusions}

In this work 28 bis(carbamoylcarboxylic) type compounds derived from two different dianhydrides and fourteen primary amines were successfully synthesized and characterized. Controlled reaction conditions were established to obtain these compounds over diimide analogs with moderate to quantitative yields. The chemo- and regioselectivity found in products derived from dianhydrides were determined by

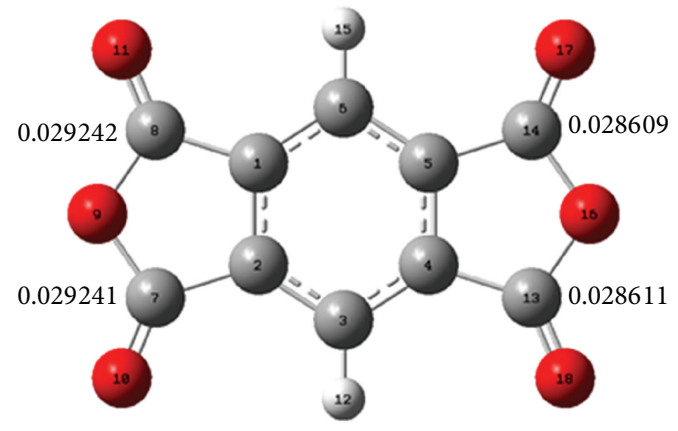

FIGURE 6: The Fukui function calculated for atoms involved in the ring-opening of dianhydride 2 .

NMR spectroscopy and supported by theoretical calculations at DFT level. We believe these products have potential uses as bioactive molecules, and as components in industrial formulations or using monotopic and ditopic ligands in the synthesis of organometallic complexes. Currently, the research group is exploring the above mentioned capabilities of the new synthesized compounds.

\section{Experimental Section}

4.1. General Information. All reagents were purchased in the highest quality available and were used without further purification. Infrared spectra (FTIR) were recorded on a spectrophotometer. Nuclear magnetic resonance ${ }^{1} \mathrm{H}$ (at $200 \mathrm{MHz}$ ) and ${ }^{13} \mathrm{C}$ (at $50 \mathrm{MHz}$ ) spectra were recorded on a $200 \mathrm{MHz}$ spectrometer in DMSO- $d_{6}$ or $\mathrm{D}_{2} \mathrm{O}$ with TMS as internal standard. Electrospray ionization mass spectra (ESIMS) were obtained with an ion trap, and the intensities are reported as a percentage relative to the base peak after the corresponding $\mathrm{m} / \mathrm{z}$ value. Electron impact mass spectra (EIMS) with direct insertion were performed on mass spectrometer. High resolution mass spectra (HRMS) were obtained with FAB (gly) or chemical ionization $\left(\mathrm{CH}_{4}\right)$ on positive or negative modes.

4.2. General Procedure for the Synthesis of 4,4'-Carbonylbis(carbamoylbenzoic) Acids. To a solution 1,2,4,5benzenetetracarboxylic dianhydride (1) $(100 \mathrm{mg}, 0.31 \mathrm{mmol})$ in $30 \mathrm{~mL}$ of $\mathrm{THF}$ or $\mathrm{EtOH}$ at $0^{\circ} \mathrm{C}$ was added the corresponding primary amine $(0.68 \mathrm{mmol}, 2.2$ equiv. $)$ and the reaction mixture was stirred at RT for $3 \mathrm{~h}$. The solid product was separated by filtration and then put into a $\mathrm{HCl}$ $5 \%$ aqueous solution in order to eliminate the unreactive 


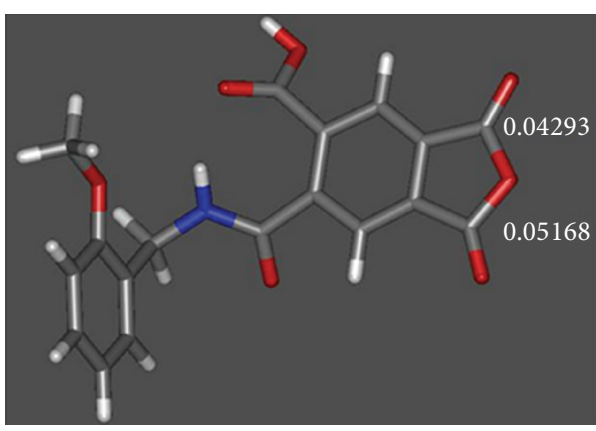

$E=-1275.173642$ a.u.

(a)

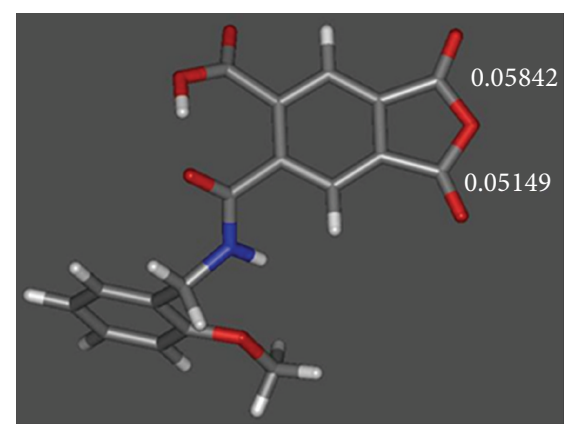

$E=-1275.177299$ a.u.

(b)

FIGURE 7: Optimized geometries of a monocarbamoylcarboxylic acid intermediate indicating Fukui function values. (a) No intramolecular hydrogen bond. (b) Intramolecular hydrogen bond.

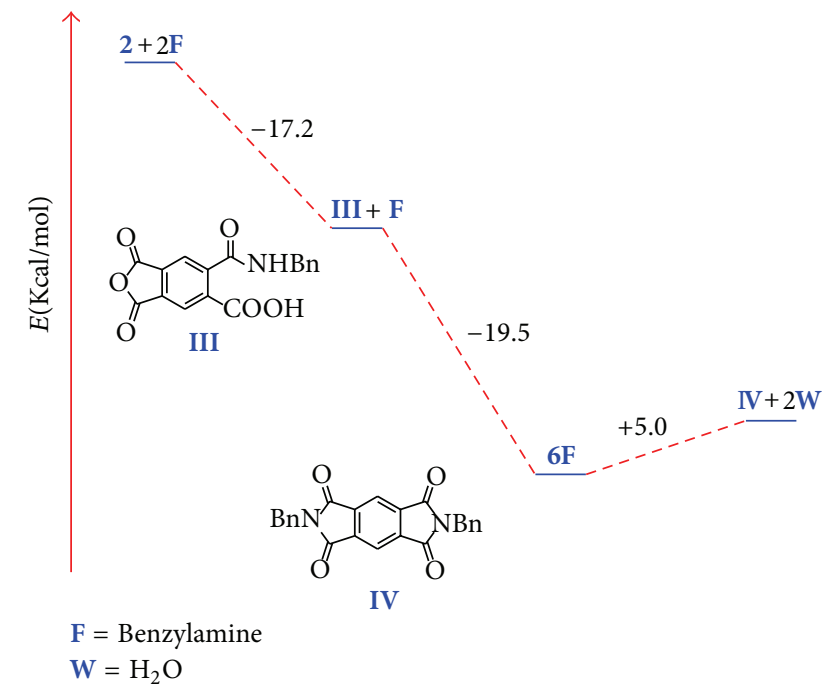

FIGURE 8: Energy diagram for the reaction pathway of dianhydride 2 and benzylamine.

amine. The solid was recovered by filtration and washed tin ethyl acetate and methylene chloride.

4,4'-Carbonyl Bis(2-(pyridin-4-ylcarbamoyl)benzoic Acid) (3A). White solid. $148 \mathrm{mg}, 0.29 \mathrm{mmol}, 92 \%$. Mp 340-342 ${ }^{\circ} \mathrm{C}$ FTIR: $3220,3098,2927,1663,1650,1599,1455,1366 \mathrm{~cm}^{-1}$. MS (EI) $m / z: 474\left(\mathrm{M}^{+}-2 \mathrm{H}_{2} \mathrm{O}, 2\right), 398$ (90), 354 (23), 322 (10), 278 (87), 103 (100), 75 (95). ${ }^{1} \mathrm{H}$ NMR (DMSO- $d_{6}, 200 \mathrm{MHz}$ ): $\delta 8.52(\mathrm{~d}, J=2.0 \mathrm{~Hz}, 2 \mathrm{H}), 8.33(\mathrm{~d}, J=8.2 \mathrm{~Hz}, 2 \mathrm{H}), 8.09$ (d, $J=7.0 \mathrm{~Hz}, 4 \mathrm{H}), 7.93$ (brs, $2 \mathrm{H}), 7.87$ (dd, $J=8.2,2.0 \mathrm{~Hz}$, $2 \mathrm{H}), 6.77(\mathrm{~d}, \mathrm{~J}=7.0 \mathrm{~Hz}, 4 \mathrm{H}), 4.60$ (brs, $2 \mathrm{H}) .{ }^{13} \mathrm{C} \mathrm{NMR}$ $\left(\mathrm{DMSO}-d_{6}, 50 \mathrm{MHz}\right): \delta$ 194.7, 167.3, 167.2, 159.7, 140.3, 138.5, 137.9, 135.0, 133.9, 133.1, 131.0, 108.9. HRMS (CI-) Calculated for $\mathrm{C}_{27} \mathrm{H}_{14} \mathrm{~N}_{4} \mathrm{O}_{5}\left(\mathrm{M}-2 \mathrm{H}_{2} \mathrm{O}\right)^{-}$474.0964; Found 474.0961.

4,4'-Carbonyl Bis(2-(pyridin-2-ylmethylcarbamoyl)benzoic Acid) (3B). White solid. $102 \mathrm{mg}, 0.19 \mathrm{mmol}, 60 \%$. Mp 138-140 C. FTIR: 3321, 2048, 2860, 1656, 1641, 1595, 1543,
$1354 \mathrm{~cm}^{-1}$. MS (EI) m/z: $502\left(\mathrm{M}^{+}-2 \mathrm{H}_{2} \mathrm{O}, 2\right), 412$ (55), 367 (22), 321 (25), 278 (100), 174 (50). ${ }^{1} \mathrm{H}$ NMR (DMSO- $d_{6}$, $200 \mathrm{MHz}): \delta 8.56(\mathrm{~s}, 2 \mathrm{H}), 8.54(\mathrm{~d}, J=2.0 \mathrm{~Hz}, 2 \mathrm{H}), 8.34(\mathrm{~d}$, $J=8.2 \mathrm{~Hz}, 2 \mathrm{H}), 7.87(\mathrm{dd}, J=8.2,2.0 \mathrm{~Hz}, 2 \mathrm{H}), 7.81(\mathrm{dd}$, $J=7.6,1.8 \mathrm{~Hz}, 4 \mathrm{H}), 7.45(\mathrm{~d}, J=7.8 \mathrm{~Hz}, 2 \mathrm{H}), 7.31(\mathrm{dd}, J=6.2$, $5.0 \mathrm{~Hz}, 2 \mathrm{H}), 4.01(\mathrm{~s}, 4 \mathrm{H}) .{ }^{13} \mathrm{C}$ NMR (DMSO- $\left.d_{6}, 50 \mathrm{MHz}\right): \delta$ 194.7, 167.2, 167.1, 157.5, 148.8, 138.5, 137.8, 136.9, 135.0, 133.9, 133.0, 130.9, 122.6, 121.8, 44.8. HRMS (CI-) Calculated for $\mathrm{C}_{29} \mathrm{H}_{18} \mathrm{~N}_{4} \mathrm{O}_{5}\left(\mathrm{M}-2 \mathrm{H}_{2} \mathrm{O}\right)^{-}$502.1277; Found 502.1280.

4,4'-Carbonyl Bis(2-(pyridin-3-ylmethylcarbamoyl)benzoic Acid) (3C). White solid. $108 \mathrm{mg}, 0.20 \mathrm{mmol}, 63 \%$. Mp 116$118^{\circ}$ C. FTIR: 3387, 3043, 2967, 2868, 1649, 1635, 1602, 1538, $1388,1358 \mathrm{~cm}^{-1}$. MS (EI) m/z: $502\left(\mathrm{M}^{+}-2 \mathrm{H}_{2} \mathrm{O}, 3\right), 411(10)$, 320 (15), 174 (100). ${ }^{1} \mathrm{H}$ NMR (DMSO- $d_{6}, 200 \mathrm{MHz}$ ): $\delta 8.55$ $(\mathrm{s}, 2 \mathrm{H}), 8.52(\mathrm{~d}, J=1.8 \mathrm{~Hz}, 2 \mathrm{H}), 8.33(\mathrm{~d}, J=8.0 \mathrm{~Hz}, 2 \mathrm{H})$, $7.86(\mathrm{dd}, J=8.0,1.8 \mathrm{~Hz}, 4 \mathrm{H}), 7.80(\mathrm{td}, J=7.6,1.8 \mathrm{~Hz}, 2 \mathrm{H})$, $7.45(\mathrm{~d}, J=7.6 \mathrm{~Hz}, 4 \mathrm{H}), 7.30$ (t, $J=7.6,2 \mathrm{H}), 5.18$ (brs, 2H), $4.01(\mathrm{~s}, 4 \mathrm{H}) .{ }^{13} \mathrm{C}$ NMR (DMSO- $\left.d_{6}, 50 \mathrm{MHz}\right): \delta 194.7,167.2$, $167.1,157.8,148.7,138.5,137.8,136.8,135.0,133.9,133.0,130.8$, 122.4, 121.7, 44.9. HRMS (CI-) Calculated for $\mathrm{C}_{29} \mathrm{H}_{18} \mathrm{~N}_{4} \mathrm{O}_{5}$ $\left(\mathrm{M}-2 \mathrm{H}_{2} \mathrm{O}\right)^{-}$502.1277; Found 502.1280.

4,4'-Carbonyl Bis(2-(pyridin-4-ylmethylcarbamoyl)benzoic Acid) (3D). White solid. $167 \mathrm{mg}, 0.31 \mathrm{mmol},>98 \%$. Mp 178-180 ․ FTIR: 3134, 3032, 2906, 2811, 1660, 1633, 1604, $1517,1382,1364 \mathrm{~cm}^{-1}$. MS (EI) $m / z: 502\left(\mathrm{M}^{+}-2 \mathrm{H}_{2} \mathrm{O}, 3\right), 412$ (10), 321 (15), 278 (100), 174 (60). ${ }^{1} \mathrm{H}$ NMR (DMSO- $d_{6}$, $200 \mathrm{MHz}): \delta 8.54(\mathrm{~d}, J=6.0 \mathrm{~Hz}, 4 \mathrm{H}), 8.53(\mathrm{~d}, J=2.0 \mathrm{~Hz}$, $1 \mathrm{H}), 8.33(\mathrm{~d}, J=8.2 \mathrm{~Hz}, 2 \mathrm{H}), 7.87(\mathrm{dd}, J=8.2,2.0 \mathrm{~Hz}, 2 \mathrm{H})$, $7.40(\mathrm{~d}, J=6.0 \mathrm{~Hz}, 4 \mathrm{H}), 5.62$ (brs, $2 \mathrm{H}), 3.93(\mathrm{~s}, 4 \mathrm{H}) \cdot{ }^{13} \mathrm{C}$ NMR (DMSO- $\left.d_{6}, 50 \mathrm{MHz}\right): \delta 194.6,167.3,167.2,149.5,147.7$, 138.5, 137.8, 135.0, 133.9, 133.0, 130.8, 122.6, 42.7. HRMS (CI-) Calculated for $\mathrm{C}_{29} \mathrm{H}_{18} \mathrm{~N}_{4} \mathrm{O}_{5}\left(\mathrm{M}-2 \mathrm{H}_{2} \mathrm{O}\right)^{-}$502.1277; Found 502.1252 .

4,4'-Carbonyl Bis(2-(phenylcarbamoyl)benzoic Acid) (3E). White solid. $132 \mathrm{mg}, 0.26 \mathrm{mmol}, 83 \%$. FTIR: 3354, 3036, 1705, $1657,1599,1495,1230 \mathrm{~cm}^{-1}$. Mp 318-320 C. MS (EI) $\mathrm{m} / z: 472$ $\left(\mathrm{M}^{+}-2 \mathrm{H}_{2} \mathrm{O}, 3\right), 397$ (40), 322 (30), 278 (100), 175 (25), 103 (60). 
${ }^{1} \mathrm{H}$ NMR (DMSO- $\left.d_{6}, 200 \mathrm{MHz}\right): \delta 8.09(\mathrm{~d}, J=1.4 \mathrm{~Hz}, 2 \mathrm{H})$, $7.95(\mathrm{dd}, J=8.0,1.4 \mathrm{~Hz}, 2 \mathrm{H}), 7.89(\mathrm{t}, J=7.4 \mathrm{~Hz}, 4 \mathrm{H}), 7.60$ (brs, $2 \mathrm{H}), 7.05$ (dd, $J=8.4,7.4 \mathrm{~Hz}, 4 \mathrm{H}), 6.63(\mathrm{~d}, J=7.8 \mathrm{~Hz}$, $4 \mathrm{H}), 6.57(\mathrm{t}, J=8.4 \mathrm{~Hz}, 2 \mathrm{H}) .{ }^{13} \mathrm{C}$ NMR (DMSO- $\left.d_{6}, 50 \mathrm{MHz}\right)$ : $\delta$ 193.5, 168.2, 167.4, 146.9, 137.8, 137.4, 132.5, 132.1, 130.1, 129.1 128.9, 117.0, 114.8. HRMS (CI-) Calculated for $\mathrm{C}_{29} \mathrm{H}_{16} \mathrm{~N}_{2} \mathrm{O}_{5}$ $\left(\mathrm{M}-2 \mathrm{H}_{2} \mathrm{O}\right)^{-}$472.1059; Found 472.1048.

4,4'-Carbonyl Bis(2-(benzylcarbamoyl)benzoic Acid) (3F). White solid. $140 \mathrm{mg}, 0.26 \mathrm{mmol}, 85 \%$. Mp 156-158 C. MS (EI) $m / z: 500\left(\mathrm{M}^{+}-2 \mathrm{H}_{2} \mathrm{O}, 100\right), 423$ (20), 409 (25), 208 (18), 91 (95). FTIR (KBr): 3032, 2938, 1655, 1243, $1084 \mathrm{~cm}^{-1} \cdot{ }^{1} \mathrm{H}$ NMR $\left(\mathrm{DMSO}-d_{6}, 200 \mathrm{MHz}\right): \delta 8.52(\mathrm{~d}, J=2.0 \mathrm{~Hz}, 2 \mathrm{H}), 8.33(\mathrm{~d}$, $J=8.0 \mathrm{~Hz}, 2 \mathrm{H}), 7.86(\mathrm{dd}, J=8.0,2.0 \mathrm{~Hz}, 2 \mathrm{H}), 7.36(\mathrm{~m}, 10 \mathrm{H})$, 5.48 (brs, 2H), 3.95 (s, 4H). ${ }^{13} \mathrm{C} \mathrm{NMR}$ (DMSO- $d_{6}, 50 \mathrm{MHz}$ ): $\delta 194.7,167.3,167.2,138.6,137.8,133.9,132.9,130.8,128.5,128.3$, 127.8, 43.3. HRMS (CI-) Calculated for $\mathrm{C}_{31} \mathrm{H}_{20} \mathrm{~N}_{2} \mathrm{O}_{5}$ (M$\left.2 \mathrm{H}_{2} \mathrm{O}\right)^{-}$500.1372; Found 500.1378.

4,4'-Carbonyl Bis(2-(2,6-difluorobenzylcarbamoyl)benzoic Acid) (3G). White solid. $189 \mathrm{mg}, 0.31 \mathrm{mmol}$, >98\%. Mp 146$148^{\circ}$ C. FTIR: 3389, 3058, 1660, 1630, 1537, 1468, $1239 \mathrm{~cm}^{-1}$. MS (EI) $m / z: 572\left(\mathrm{M}^{+}-2 \mathrm{H}_{2} \mathrm{O}, 20\right), 447$ (10), 320 (45), 375 (40), 127 (100). ${ }^{1} \mathrm{H}$ NMR (DMSO- $d_{6}, 200 \mathrm{MHz}$ ): $\delta 8.52$ (d, $J=2.0 \mathrm{~Hz}, 2 \mathrm{H}), 8.33(\mathrm{~d}, J=8.2 \mathrm{~Hz}, 2 \mathrm{H}), 7.86(\mathrm{dd}, J=8.2$, $2.0 \mathrm{~Hz}, 2 \mathrm{H}$ ), 7.44 (qnt, $J=8.0 \mathrm{~Hz}, 4 \mathrm{H}), 7.12$ (t, $J=8.0,2 \mathrm{H}$ ), 4.60 (brs, $2 \mathrm{H}), 3.90$ (s, 4H). ${ }^{13} \mathrm{C}$ NMR (DMSO- $\left.d_{6}, 50 \mathrm{MHz}\right)$ : $\delta 194.6,167.1,167.0,160.8(\mathrm{dd}, J=246.1,8.4 \mathrm{~Hz}), 138.4$, 137.7, 134.9, 133.9, 133.0, 130.8, $130.4(\mathrm{t}, J=10.4 \mathrm{~Hz}) 111.6(\mathrm{~d}$, $J=23.9 \mathrm{~Hz}), 111.5(\mathrm{~d}, J=22.5 \mathrm{~Hz}), 31.7(\mathrm{t}, J=4 \mathrm{~Hz})$. HRMS (CI-) Calculated for $\mathrm{C}_{31} \mathrm{H}_{16} \mathrm{~F}_{4} \mathrm{~N}_{2} \mathrm{O}_{5}\left(\mathrm{M}-2 \mathrm{H}_{2} \mathrm{O}\right)^{-}$572.0995; Found 572.1003.

4,4'-Carbonyl Bis(2-(2-chlorobenzylcarbamoyl)benzoic Acid) (3H). White solid. $188 \mathrm{mg}, 0.31 \mathrm{mmol},>98 \%$. Mp $122-124^{\circ} \mathrm{C}$. FTIR: 3235, 3010, 2967, 1700, 1631, 1516, $1274 \mathrm{~cm}^{-1}$. MS (EI) $\mathrm{m} / z: 533\left(\mathrm{M}^{+}-\mathrm{Cl}-2 \mathrm{H}_{2} \mathrm{O}, 100\right), 427(10), 249(25), 125(30) .{ }^{1} \mathrm{H}$ NMR (DMSO- $\left.d_{6}, 200 \mathrm{MHz}\right): \delta 8.52(\mathrm{~d}, J=2.0 \mathrm{~Hz}, 2 \mathrm{H}), 8.33$ $(\mathrm{d}, J=8.0 \mathrm{~Hz}, 2 \mathrm{H}), 7.86(\mathrm{dd}, J=8.0,2.0 \mathrm{~Hz}, 2 \mathrm{H}), 7.56(\mathrm{dd}$, $J=7.2,2.6 \mathrm{~Hz}, 2 \mathrm{H}), 7.47(\mathrm{dd}, J=7.0,2.4 \mathrm{~Hz}, 2 \mathrm{H}), 7.37$ (m, 4H), 4.37 (brs, 2H), 3.97 (s, $4 \mathrm{H}) .{ }^{13} \mathrm{C}$ NMR (DMSO-d 6 , $50 \mathrm{MHz}): \delta 194.6,167.1,167.0,138.5,137.8,134.9,133.9,133.0$, $132.4,130.8,129.7,129.3,129.2,129.1,127.3,41.3$. HRMS (CI-) Calculated for $\mathrm{C}_{31} \mathrm{H}_{18} \mathrm{Cl}_{2} \mathrm{~N}_{2} \mathrm{O}_{5}\left(\mathrm{M}-2 \mathrm{H}_{2} \mathrm{O}\right)^{-}$568.0593; Found 568.0622 .

4,4'-Carbonyl Bis(2-(2-methoxybenzylcarbamoyl)benzoic Acid) (3I). White solid. $185 \mathrm{mg}, 0.31 \mathrm{mmol},>98 \%$. Mp 186$188^{\circ} \mathrm{C}$. FTIR: $3254,2997,1656,1629,1522,1257,1268 \mathrm{~cm}^{-1}$. MS (EI) $m / z: 560\left(\mathrm{M}^{+}-2 \mathrm{H}_{2} \mathrm{O}, 45\right), 439$ (30), 333 (18), 121 (100). ${ }^{1} \mathrm{H}$ NMR (DMSO- $\left.d_{6}, 200 \mathrm{MHz}\right): \delta 8.52(\mathrm{~d}, J=2.0 \mathrm{~Hz}$, $2 \mathrm{H}), 8.33(\mathrm{~d}, J=8.2,2 \mathrm{H}), 7.85(\mathrm{dd}, J=8.2,2.0 \mathrm{~Hz}, 2 \mathrm{H}), 7.33$ $(\mathrm{d}, J=8.2 \mathrm{~Hz}, 2 \mathrm{H}), 7.28(\mathrm{dd}, J=7.4,1.7 \mathrm{~Hz}, 2 \mathrm{H}), 7.00(\mathrm{~d}$, $J=8.2 \mathrm{~Hz}, 2 \mathrm{H}), 6.94(\mathrm{t}, J=7.4 \mathrm{~Hz}, 2 \mathrm{H}), 4.00$ (brs, $2 \mathrm{H}), 3.83$ $(\mathrm{s}, 2 \mathrm{H}), 3.80(\mathrm{~s}, 4 \mathrm{H}) .{ }^{13} \mathrm{C}$ NMR (DMSO-d $\left.6,50 \mathrm{MHz}\right): \delta$ 194.7, $167.1,167.0,156.9,138.5,137.8,135.0,133.9,133.0,130.8,129.1$, 129.0, 126.2, 120.2, 110.5, 55.3, 39.1. HRMS (CI-) Calculated for $\mathrm{C}_{33} \mathrm{H}_{24} \mathrm{~N}_{2} \mathrm{O}_{7}\left(\mathrm{M}-2 \mathrm{H}_{2} \mathrm{O}\right)^{-}$560.1584; Found 560.1609 .
4,4'-Carbonyl Bis(2-(2-methoxyphenethylcarbamoyl)benzoic Acid) (3J). White solid. $186 \mathrm{mg}, 0.30 \mathrm{mmol}, 96 \%$. Mp $112-$ $114^{\circ} \mathrm{C}$. FTIR: $3335,2981,1706,1635,1575,1356 \mathrm{~cm}^{-1}$. MS (EI) $m / z: 588\left(\mathrm{M}^{+}-2 \mathrm{H}_{2} \mathrm{O}, 7\right), 455(14), 278(25), 134$ (100). ${ }^{1} \mathrm{H}$ NMR $\left(\mathrm{DMSO}_{6}, 200 \mathrm{MHz}\right): \delta 8.47(\mathrm{~d}, J=1.8 \mathrm{~Hz}, 2 \mathrm{H}), 8.27(\mathrm{~d}, J=$ $8.0 \mathrm{~Hz}, 2 \mathrm{H}), 7.83(\mathrm{dd}, J=8.0,1.8 \mathrm{~Hz}, 2 \mathrm{H}), 7.20(\mathrm{dd}, J=8.0$, $1.6 \mathrm{~Hz}, 2 \mathrm{H}), 7.13(\mathrm{dd}, J=7.4,1.6 \mathrm{~Hz}, 2 \mathrm{H}), 6.95(\mathrm{~d}, J=8.0 \mathrm{~Hz}$, $2 \mathrm{H}), 6.86(\mathrm{t}, J=7.4 \mathrm{~Hz}, 2 \mathrm{H}), 4.00$ (brs, $2 \mathrm{H}), 3.76(\mathrm{~s}, 6 \mathrm{H})$, $2.78(\mathrm{~m}, 8 \mathrm{H}) .{ }^{13} \mathrm{C}$ NMR (DMSO- $\left.d_{6}, 50 \mathrm{MHz}\right): \delta$ 194.8, 167.7, $167.5,157.2,137.7,135.3,133.7,132.8,132.7,130.8,130.1,127.9$, 126.3, 120.4 , 110.8, 55.3, 48.7, 30.8. HRMS (CI-) Calculated for $\mathrm{C}_{35} \mathrm{H}_{28} \mathrm{~N}_{2} \mathrm{O}_{7}\left(\mathrm{M}-2 \mathrm{H}_{2} \mathrm{O}\right)^{-}$588.1897; Found 588.1866.

4,4'-Carbonyl Bis(2-(3-phenylpropylcarbamoyl)benzoic Acid) (3K). Yellow oil. $116 \mathrm{mg}, 0.20 \mathrm{mmol}, 63 \%$. FTIR: 3381, 3024, $1699,1649,1549,1356,1238 \mathrm{~cm}^{-1}$. MS (EI) m/z: $556\left(\mathrm{M}^{+}\right.$$\left.2 \mathrm{H}_{2} \mathrm{O}, 5\right), 439$ (50), 335 (100), 278 (90). ${ }^{1} \mathrm{H}$ NMR (DMSO- $d_{6}$, $200 \mathrm{MHz}): \delta 8.42(\mathrm{~d}, J=1.8 \mathrm{~Hz}, 2 \mathrm{H}), 8.19(\mathrm{~d}, J=8.0 \mathrm{~Hz}, 2 \mathrm{H})$, $7.80(\mathrm{~d}, J=8.0,1.8 \mathrm{~Hz}, 2 \mathrm{H}), 7.30-7.15(\mathrm{~m}, 10 \mathrm{H}), 4.85$ (brs, $2 \mathrm{H})$, $2.73(\mathrm{t}, J=7.4 \mathrm{~Hz}, 4 \mathrm{H}), 2.59(\mathrm{t}, J=7.4 \mathrm{~Hz}, 4 \mathrm{H}), 1.78$ (qnt, $J=$ $7.4 \mathrm{~Hz}, 4 \mathrm{H}) .{ }^{13} \mathrm{C}$ NMR (DMSO- $\left.d_{6}, 50 \mathrm{MHz}\right): \delta 194.8,168.3$, $168.1,141.2,139.6,139.5,137.5,135.7,133.2,132.0,130.5,128.4$, 128.2, 121.1, 125.9, 39.0, 32.0, 30.1. HRMS (CI-) Calculated for $\mathrm{C}_{35} \mathrm{H}_{28} \mathrm{~N}_{2} \mathrm{O}_{5}\left(\mathrm{M}-2 \mathrm{H}_{2} \mathrm{O}\right)^{-}$556.1998; Found 556.2010.

4,4'-Carbonyl Bis(2-(2-phenoxyethylcarbamoyl)benzoic Acid) (3L). Yellow oil. $137 \mathrm{mg}, 0.23 \mathrm{mmol}, 74 \%$. FTIR: 3378, 3040, $1714,1641,1491,1361,1238 \mathrm{~cm}^{-1}$. MS (EI) $m / z: 560\left(\mathrm{M}^{+}-\right.$ $\left.2 \mathrm{H}_{2} \mathrm{O}, 6\right), 467$ (35), 348 (100), 120 (30). ${ }^{1} \mathrm{H}$ NMR (DMSO- $d_{6}$, $200 \mathrm{MHz}): \delta 8.50(\mathrm{~d}, J=2.0 \mathrm{~Hz}, 2 \mathrm{H}), 8.31(\mathrm{~d}, J=8.0 \mathrm{~Hz}, 2 \mathrm{H})$, $7.85(\mathrm{dd}, J=8.0,2.0 \mathrm{~Hz}, 2 \mathrm{H}), 7.29(\mathrm{dd}, J=7.6,7.2 \mathrm{~Hz}, 4 \mathrm{H})$, $7.00-6.88(\mathrm{~m}, 6 \mathrm{H}), 4.02(\mathrm{t}, J=5.4 \mathrm{~Hz}, 4 \mathrm{H}), 3.98$ (brs, $2 \mathrm{H})$, 3.04 (brt, $4 \mathrm{H}) .{ }^{13} \mathrm{C}$ NMR (DMSO- $\left.d_{6}, 50 \mathrm{MHz}\right): \delta 194.8,167.4$, 167.3, 158.3, 138.7, 137.9, 135.1, 133.9, 133.0, 130.9, 129.6, 120.9, 114.6, 67.2, 39.8. HRMS (CI-) Calculated for $\mathrm{C}_{33} \mathrm{H}_{24} \mathrm{~N}_{2} \mathrm{O}_{7}$ $\left(\mathrm{M}-2 \mathrm{H}_{2} \mathrm{O}\right)^{-}$560.1584; Found 560.1534.

4,4'-Carbonyl Bis(2-(naphthalen-1-ylcarbamoyl)benzoic Acid) (3M). White solid. $189 \mathrm{mg}, 0.31 \mathrm{mmol},>98 \%$. Mp 198-200 ${ }^{\circ} \mathrm{C}$. FTIR: $3374,2970,1699,1657,1510,1364,1238 \mathrm{~cm}^{-1}$. MS (EI) $m / z: 572\left(\mathrm{M}^{+}-2 \mathrm{H}_{2} \mathrm{O}, 5\right), 447$ (100), $278(20), 228$ (25), 127 (40). ${ }^{1} \mathrm{H}$ NMR (DMSO- $\left.d_{6}, 200 \mathrm{MHz}\right): \delta 8.06(\mathrm{~d}, J=1.6 \mathrm{~Hz}, 2 \mathrm{H})$, 8.05-8.03 (m, 2H), 7.95 (dd, $J=8.0,1.6 \mathrm{~Hz}, 2 \mathrm{H}), 7.84$ (d, $J=$ $7.8 \mathrm{~Hz}, 2 \mathrm{H}), 7.73(\mathrm{dd}, J=7.0,2.6 \mathrm{~Hz}, 2 \mathrm{H}), 7.75-7.46(\mathrm{~m}, 4 \mathrm{H})$, $7.21(\mathrm{dd}, J=8.0,7.4 \mathrm{~Hz}, 2 \mathrm{H}), 7.10(\mathrm{~d}, J=7.8,2 \mathrm{H}), 6.70(\mathrm{dd}$, $J=7.4,1.4 \mathrm{~Hz}, 2 \mathrm{H}), 4.22$ (brs, $2 \mathrm{H}) .{ }^{13} \mathrm{C} \mathrm{NMR}$ (DMSO- $d_{6}$, $50 \mathrm{MHz}$ ): $\delta 193.4,168.3,167.4,144.0,137.8,137.3,134.1,132.3$, $132.2,129.8,128.8,127.8,126.7,125.5,123.8,122.9,122.3,116.0$, 108.0. HRMS (CI-) Calculated for $\mathrm{C}_{37} \mathrm{H}_{20} \mathrm{~N}_{2} \mathrm{O}_{5}\left(\mathrm{M}-2 \mathrm{H}_{2} \mathrm{O}\right)^{-}$ 572.1372; Found 572.1355.

4,4'-Carbonyl Bis(2-(naphthalen-1-ylmethylcarbamoyl)benzoic Acid) (3N). White solid. $193 \mathrm{mg}, 0.30 \mathrm{mmol}, 98 \% . \mathrm{Mp}$ 200-202 $2^{\circ}$. MS (EI) m/z: $600\left(\mathrm{M}^{+}-2 \mathrm{H}_{2} \mathrm{O}, 70\right), 472$ (30), 141 (100). FTIR: $3124,3048,2926,1657,1625,1602,1518 \mathrm{~cm}^{-1} .{ }^{1} \mathrm{H}$ NMR (DMSO- $\left.d_{6}, 200 \mathrm{MHz}\right): \delta 8.52(\mathrm{~d}, J=2.0 \mathrm{~Hz} ; 2 \mathrm{H}), 8.32$ $(\mathrm{d}, J=8.2 \mathrm{~Hz}, 2 \mathrm{H}), 8.13(\mathrm{~d}, J=8.2,2 \mathrm{H}), 7.97(\mathrm{~d}, J=8.0$, 
$\mathrm{Hz}, 4 \mathrm{H}), 7.89(\mathrm{~d}, J=8.0 \mathrm{~Hz}, 2 \mathrm{H}), 7.86(\mathrm{dd}, J=8.2,2.0 \mathrm{~Hz}$, $2 \mathrm{H}), 7.62-7.50(\mathrm{~m}, 8 \mathrm{H}), 4.37(\mathrm{~s}, 4 \mathrm{H}) .{ }^{13} \mathrm{C}$ NMR (DMSO- $d_{6}$, $50 \mathrm{MHz}): \delta 194.7,167.1,167.0,138.5,137.8,135.0,134.4,133.9$, 133.2, 133.0, 130.8, 128.5, 127.9, 126.3, 125.9, 125.8, 125.4, 123.4, 41.1. HRMS (CI-) Calculated for $\mathrm{C}_{39} \mathrm{H}_{24} \mathrm{~N}_{2} \mathrm{O}_{5}\left(\mathrm{M}-2 \mathrm{H}_{2} \mathrm{O}\right)^{-}$ 600.1685; Found 600.1639.

\subsection{General Procedure for the Synthesis of Bis(carbamoyl) Terephthalic Acids}

Method 1. To a solution 1,2,4,5-benzenetetracarboxylic dianhydride (2) (100 mg, $0.46 \mathrm{mmol})$ in $30 \mathrm{~mL}$ of THF or EtOH at $0^{\circ} \mathrm{C}$ the corresponding primary amine was added $(1.01 \mathrm{mmol}$, 2.2 equiv.) and the reaction mixture was stirred at RT for $3 \mathrm{~h}$. The solid product was separated by filtration and then put into an $\mathrm{HCl} 5 \%$ aqueous solution in order to eliminate the unreactive amine. The solid was recovered by filtration and washed with ethyl acetate and methylene chloride.

Method 2. To a solution 1,2,4,5-benzenetetracarboxylic dianhydride (2) (100 mg, $0.46 \mathrm{mmol})$ in $30 \mathrm{~mL}$ of THF or Toluene was added the corresponding primary amine $(1.01 \mathrm{mmol}$, 2.2 equiv.) and the reaction mixture was refluxed for $4 \mathrm{~h}$. The solid product was separated by filtration and then put into an $\mathrm{HCl} 5 \%$ aqueous solution in order to eliminate the unreactive amine. The solid was recovered by filtration and washed with ethyl acetate and methylene chloride.

2,5-Bis(pyridin-4-ylcarbamoyl)terephthalic Acid (6A). White solid. $187 \mathrm{mg}, 0.46 \mathrm{mmol}$, >98\%. Mp 290-292 C. FTIR: 3302, $3097,1701,1640,1565,1490 \mathrm{~cm}^{-1}$. EIMS m/z: $370\left(\mathrm{M}^{+}-2 \mathrm{H}_{2} \mathrm{O}\right.$, 11), 174 (100), 102 (50), 74 (40). MS (ESI-) m/z: $405(\mathrm{M}-\mathrm{H})^{-}$ MS/MS: 405 (2), 361 (5), 317 (100). ${ }^{1} \mathrm{H}$ NMR (DMSO- $d_{6}$, $200 \mathrm{MHz}$ ): $\delta 8.95$ (s, 2H), $8.10(\mathrm{~d}, J=7.2 \mathrm{~Hz}, 4 \mathrm{H}), 7.86(\mathrm{~s}$, $2 \mathrm{H}), 6.76(\mathrm{~d}, J=7.2 \mathrm{~Hz}, 4 \mathrm{H}), 4.41$ (brs, $2 \mathrm{H}) .{ }^{13} \mathrm{C} \mathrm{NMR}$ (DMSO- $\left.d_{6}, 50 \mathrm{MHz}\right): \delta 168.3,168.1,158.1,143.0,134.1,129.0$, 127.6. HRMS (CI+) Calculated for $\mathrm{C}_{20} \mathrm{H}_{11} \mathrm{~N}_{4} \mathrm{O}_{4}\left(\mathrm{M}-2 \mathrm{H}_{2} \mathrm{O}+1\right)$ 371.0780; Found 371.0801.

2,5-Bis(pyridin-2-ylmethylcarbamoyl)terephthalic Acid (6B). White solid. $136 \mathrm{mg}, 0.31 \mathrm{mmol}, 68 \%$. Mp 218-220 C. FTIR: $3242,3065,2919,1702,1641,1633,1550,1291,1254 \mathrm{~cm}^{-1}$. MS (EI) $m / z: 398\left(\mathrm{M}^{+}-2 \mathrm{H}_{2} \mathrm{O}, 100\right), 353$ (70), 308 (50), 263 (30). ${ }^{1} \mathrm{H}$ NMR $\left(\mathrm{D}_{2} \mathrm{O}-\mathrm{DCl}, 200 \mathrm{MHz}\right): \delta 8.74(\mathrm{~d}, J=6.6 \mathrm{~Hz}, 2 \mathrm{H})$, $8.61(\mathrm{t}, J=8.8 \mathrm{~Hz}, 2 \mathrm{H}), 8.15(\mathrm{~s}, 2 \mathrm{H}), 8.12(\mathrm{~d}, J=8.8 \mathrm{~Hz}, 2 \mathrm{H})$, $8.00(\mathrm{t}, J=6.6 \mathrm{~Hz}, 2 \mathrm{H}), 4.96(\mathrm{~s}, 4 \mathrm{H}) .{ }^{13} \mathrm{C}$ NMR $\left(\mathrm{D}_{2} \mathrm{O}-\mathrm{DCl}\right.$, $50 \mathrm{MHz}): \delta 171.5,168.0,152.1,147.6,141.1,137.7,132.7,129.8$, 126.3, 126.2, 41.2. HRMS (CI+) Calculated for $\mathrm{C}_{22} \mathrm{H}_{15} \mathrm{~N}_{4} \mathrm{O}_{4}$ $\left(\mathrm{M}-2 \mathrm{H}_{2} \mathrm{O}+1\right)$ 399.1093; Found 399.1082.

2,5-Bis(pyridin-3-ylmethylcarbamoyl)terephthalic Acid (6C). White solid. $178 \mathrm{mg}, 0.42 \mathrm{mmol}, 89 \%$. Mp 264-266 C. FTIR: $3250,3001,2911,1654,1628,1521,1405,1336 \mathrm{~cm}^{-1}$. MS (EI) $m / z: 398\left(\mathrm{M}^{+}-2 \mathrm{H}_{2} \mathrm{O}, 100\right), 238(40), 208(10)$. MS (ESI+) $m / z$ : $435(\mathrm{M}+\mathrm{H})^{+}$. MS (ESI-) $m / z: 433(\mathrm{M}-\mathrm{H})^{-} \mathrm{MS} / \mathrm{MS} 433(2)$, 390(15), 346(100). ${ }^{1} \mathrm{H}$ NMR ( $\left.\mathrm{D}_{2} \mathrm{O}-\mathrm{DCl}, 200 \mathrm{MHz}\right): \delta 8.82(\mathrm{~s}$, $2 \mathrm{H}), 8.72(\mathrm{~d}, J=6.0 \mathrm{~Hz}, 2 \mathrm{H}), 8.63(\mathrm{dt}, J=8.2,1.8 \mathrm{~Hz}, 2 \mathrm{H})$, 8.08 (s, 2H), 8.06 (dd, $J=8.2,6.0 \mathrm{~Hz}, 2 \mathrm{H}), 4.77(\mathrm{~s}, 4 \mathrm{H}) .{ }^{13} \mathrm{C}$
NMR ( $\left.\mathrm{D}_{2} \mathrm{O}-\mathrm{DCl}, 50 \mathrm{MHz}\right): \delta$ 171.2, 167.9, 146.2, 140.2, 138.5, 137.9, 134.3, 132.5, 129.8, 127.5, 40.6. HRMS (CI+) Calculated for $\mathrm{C}_{22} \mathrm{H}_{15} \mathrm{~N}_{4} \mathrm{O}_{4}\left(\mathrm{M}-2 \mathrm{H}_{2} \mathrm{O}+1\right)$ 399.1093; Found 399.1093.

2,5-Bis(pyridin-4-ylmethylcarbamoyl)terephthalic Acid (6D). White solid. $164 \mathrm{mg}, 0.38 \mathrm{mmol}, 82 \%$. Mp 296-298 C. FTIR: $3329,3064,1704,1642,1605,1535,1267 \mathrm{~cm}^{-1}$. EIMS m/z: 398 $\left(\mathrm{M}^{+}-2 \mathrm{H}_{2} \mathrm{O}, 100\right), 238$ (20), 208 (10). MS (ESI+) $\mathrm{m} / z: 435$ $(\mathrm{M}+\mathrm{H})^{+}$. MS (ESI-) $m / z: 433(\mathrm{M}-\mathrm{H})^{-} .{ }^{1} \mathrm{H}$ NMR $\left(\mathrm{D}_{2} \mathrm{O}-\mathrm{DCl}\right.$, $200 \mathrm{MHz}): \delta 8.75(\mathrm{~d}, J=6.8 \mathrm{~Hz}, 4 \mathrm{H}), 8.16(\mathrm{~s}, 2 \mathrm{H}), 8.09(\mathrm{~d}, J=$ 6.8, $4 \mathrm{H}), 4.89$ (s, $4 \mathrm{H}) .{ }^{13} \mathrm{C} \mathrm{NMR}\left(\mathrm{D}_{2} \mathrm{O}-\mathrm{DCl}, 50 \mathrm{MHz}\right): \delta 171.3$, 168.0, 159.7, 141.0, 137.9, 132.8, 129.8, 125.4, 43.1. HRMS (CI+) Calculated for $\mathrm{C}_{22} \mathrm{H}_{11} \mathrm{~N}_{4} \mathrm{O}_{4}\left(\mathrm{M}-2 \mathrm{H}_{2} \mathrm{O}+1\right)$ 399.1093; Found 399.1106 .

2,5-Bis(phenylcarbamoyl)terephthalic Acid (6E). White solid. $118 \mathrm{mg}, 0.29 \mathrm{mmol}, 63 \%$. Mp 346-348 ${ }^{\circ}$ C. FTIR: 3295, 3024, $1694,1648,1536,1264 \mathrm{~cm}^{-1}$. MS (EI) $m / z: 368\left(\mathrm{M}^{+}-2 \mathrm{H}_{2} \mathrm{O}, 6\right)$, 293 (10), $174(80), 93(100)$. MS (ESI+) $m / z: 427(\mathrm{M}+\mathrm{Na})^{+}$. MS (ESI-) $m / z: 431(\mathrm{M}-\mathrm{H})^{-}$MS/MS 431(2), 388(15), 344(100). ${ }^{1} \mathrm{H}$ NMR (DMSO- $d_{6}, 200 \mathrm{MHz}$ ): $\delta 10.53$ (s, 2H), 7.96 (s, 2H), $7.70(\mathrm{~d}, J=7.4 \mathrm{~Hz}, 4 \mathrm{H}), 7.36(\mathrm{t}, J=7.4 \mathrm{~Hz}, 4 \mathrm{H}) 7.11(\mathrm{t}$, $J=7.4 \mathrm{~Hz}, 2 \mathrm{H}) .{ }^{13} \mathrm{C}$ NMR (DMSO- $\left.d_{6}, 50 \mathrm{MHz}\right): \delta 166.6$, $165.8,141.2,139.2,139.1,132.9,128.7,123.6,119.6$. HRMS (CI) Calculated for $\mathrm{C}_{22} \mathrm{H}_{12} \mathrm{~N}_{4} \mathrm{O}_{4}\left(\mathrm{M}-2 \mathrm{H}_{2} \mathrm{O}\right)^{-}$368.0797; Found 368.0785 .

2,5-Bis(benzylcarbamoyl)terephthalic Acid (6F). White solid. $179 \mathrm{mg}, 0.41 \mathrm{mmol}, 90 \%$. Mp 280-282 C. FTIR: 3272, 3033, 2905, 1694, 1643, 1544, 1301, $1266 \mathrm{~cm}^{-1}$. MS (EI) $\mathrm{m} / z: 396$ $\left(\mathrm{M}^{+}-2 \mathrm{H}_{2} \mathrm{O}, 10\right), 307$ (20), $174(100), 106$ (100). MS (ESI+) $m / z$ : $455(\mathrm{M}+\mathrm{Na})^{+} .{ }^{1} \mathrm{H}$ NMR (DMSO- $\left.d_{6}, 200 \mathrm{MHz}\right): \delta 13.46$ (brs, 2H), 9.07 (t, $J=6.0 \mathrm{~Hz}, 2 \mathrm{H}), 7.79$ (s, 2H), $7.33(\mathrm{~m}, 10 \mathrm{H}), 4.46$ $(\mathrm{d}, J=6.0 \mathrm{~Hz}, 4 \mathrm{H}) .{ }^{13} \mathrm{C} \mathrm{NMR}\left(\mathrm{DMSO}-d_{6}, 50 \mathrm{MHz}\right): \delta 167.1$, $167.0,139.2$, 138.5, 133.3, 128.2, 127.3, 126.7, 42.6. HRMS (CI+) Calculated for $\mathrm{C}_{24} \mathrm{H}_{17} \mathrm{~N}_{2} \mathrm{O}_{4}\left(\mathrm{M}-2 \mathrm{H}_{2} \mathrm{O}+1\right)$ 397.1188; Found 397.1214.

2,5-Bis(2,6-difluorobenzylcarbamoyl)terephthalic Acid (6G). White solid. $186 \mathrm{mg}, 0.37 \mathrm{mmol}, 80 \%$. Mp 260-262 ${ }^{\circ} \mathrm{C}$. FTIR: $3205,3035,1643,1626,1589,1556,1470,1328 \mathrm{~cm}^{-1}$. MS (EI) $m / z: 468\left(\mathrm{M}^{+}-2 \mathrm{H}_{2} \mathrm{O}, 7\right), 343$ (25), 174 (100), 142 (90), 102 (40). MS (ESI+) $m / z: 526(\mathrm{M}+\mathrm{Na})^{+}, 505(\mathrm{M}+\mathrm{H})^{+}$. MS (ESI-) $m / z: 503(\mathrm{M}-\mathrm{H})^{-} .{ }^{1} \mathrm{H}$ NMR (DMSO- $\left.d_{6}, 200 \mathrm{MHz}\right): \delta 8.95(\mathrm{t}$, $J=5.2 \mathrm{~Hz}, 2 \mathrm{H}), 7.65(\mathrm{~s}, 2 \mathrm{H}), 7.40$ (qnt, $J=7.2 \mathrm{~Hz}, 2 \mathrm{H}), 7.10(\mathrm{t}$, $J=7.2 \mathrm{~Hz}, 4 \mathrm{H}), 4.47(\mathrm{~d}, J=5.2 \mathrm{~Hz}, 4 \mathrm{H}) .{ }^{13} \mathrm{C}$ NMR (DMSO$\left.d_{6}, 50 \mathrm{MHz}\right): \delta 167.0,166.8,161.2(\mathrm{dd}, J=245.5,9.1 \mathrm{~Hz})$, $138.2,133.2,130.3(\mathrm{t}, J=10.2 \mathrm{~Hz}), 128.3(\mathrm{~d}, J=27.5 \mathrm{~Hz})$, 112.0, $111.6(\mathrm{t}, J=23.7 \mathrm{~Hz}), 31.2$. HRMS (CI+) Calculated for $\mathrm{C}_{24} \mathrm{H}_{13} \mathrm{~F}_{4} \mathrm{~N}_{2} \mathrm{O}_{4}\left(\mathrm{M}-2 \mathrm{H}_{2} \mathrm{O}+1\right)$ 469.0811; Found 469.0824.

2,5-Bis(2-chlorobenzylcarbamoyl)terephthalic Acid (6H). White solid. $198 \mathrm{mg}, 0.40 \mathrm{mmol}, 86 \%$. Mp 276-278 C. FTIR: $3265,2880,1662,1638,1515,1396,1333 \mathrm{~cm}^{-1}$. MS (EI) $m / z$ : $429\left(\mathrm{M}^{+}-2 \mathrm{H}_{2} \mathrm{O}-\mathrm{Cl}, 20\right), 306$ (100), 174 (50), 106 (60). MS (ESI-) $m / z: 500(\mathrm{M}-\mathrm{H})^{-} .{ }^{1} \mathrm{H}$ NMR (DMSO- $\left.d_{6}, 200 \mathrm{MHz}\right)$ : $\delta 9.15(\mathrm{t}, J=5.8 \mathrm{~Hz}, 2 \mathrm{H}), 7.85(\mathrm{~s}, 2 \mathrm{H}), 7.62-7.24(\mathrm{~m}, 8 \mathrm{H})$, 
$4.51(\mathrm{~d}, J=5.8 \mathrm{~Hz}, 4 \mathrm{H}) .{ }^{13} \mathrm{C}$ NMR (DMSO- $\left.d_{6}, 50 \mathrm{MHz}\right): \delta$ $167.4,167.2$, 138.4, 136.0, 131.9, 130.1, 129.3, 128.8, 128.2, 127.5, 126.9, 40.6. HRMS (CI+) Calculated for $\mathrm{C}_{24} \mathrm{H}_{15} \mathrm{Cl}_{2} \mathrm{~N}_{2} \mathrm{O}_{4}$ $\left(\mathrm{M}-2 \mathrm{H}_{2} \mathrm{O}+1\right)$ 465.0409; Found 465.0374.

2,5-Bis(2-methoxybenzylcarbamoyl)terephthalic Acid (6I). White solid. $227 \mathrm{mg}, 046 \mathrm{mmol},>98 \%$. Mp 108-110 ${ }^{\circ} \mathrm{C}$ FTIR: $3291,3005,1694,1644,1540,1220 \mathrm{~cm}^{-1}$. MS (EI) $\mathrm{m} / z: 456$ $\left(\mathrm{M}^{+}-2 \mathrm{H}_{2} \mathrm{O}, 100\right), 135$ (35), 121 (40), 91 (55). MS (ESI+) $m / z$ : $493(\mathrm{M}+\mathrm{H})^{+}$. MS (ESI-) m/z: $491(\mathrm{M}-\mathrm{H})^{-} \mathrm{MS} / \mathrm{MS} 491$ (3), 443 (25), 404 (100). ${ }^{1} \mathrm{H}$ NMR (DMSO- $d_{6}, 200 \mathrm{MHz}$ ): $\delta 8.92$ $(\mathrm{t}, J=5.8 \mathrm{~Hz}, 2 \mathrm{H}), 7.81(\mathrm{~s}, 2 \mathrm{H}), 7.37(\mathrm{dd}, J=7.4,1.4 \mathrm{~Hz}, 2 \mathrm{H})$, $7.25(\mathrm{td}, J=8.2,1.6 \mathrm{~Hz}, 2 \mathrm{H}), 6.99(\mathrm{~d}, J=8.2 \mathrm{~Hz}, 2 \mathrm{H}), 6.93$ $(\mathrm{t}, J=7.4 \mathrm{~Hz}, 2 \mathrm{H}), 4.41(\mathrm{~d}, J=5.8 \mathrm{~Hz}, 4 \mathrm{H}), 3.82(\mathrm{~s}, 6 \mathrm{H})$. ${ }^{13} \mathrm{C}$ NMR (DMSO- $\left.d_{6}, 50 \mathrm{MHz}\right): \delta 167.3,167.2,156.6,138.6$, 133.4 , 129.3, 127.7, 126.6, 120.2, 110.4, 55.4, 37.7. HRMS (CI+) Calculated for $\mathrm{C}_{26} \mathrm{H}_{21} \mathrm{~N}_{2} \mathrm{O}_{6}\left(\mathrm{M}-2 \mathrm{H}_{2} \mathrm{O}+1\right)$ 457.1400; Found 457.1404 .

2,5-Bis(2-methoxyphenethylcarbamoyl)terephthalic Acid (6J). White solid. $196 \mathrm{mg}, 0.38 \mathrm{mmol}, 82 \%$. Mp 248-250 C FTIR: $3315,3006,2945,1698,1604,1568,1242 \mathrm{~cm}^{-1}$. MS (EI) $m / z$ : $484\left(\mathrm{M}^{+}-2 \mathrm{H}_{2} \mathrm{O}, 12\right), 174$ (30), 134 (85), 91 (100). MS (ESI-) $\mathrm{m} / z: 519(\mathrm{M}-\mathrm{H})^{-}, \mathrm{MS} / \mathrm{MS} 519$ (2), 475 (42), 431 (100). ${ }^{1} \mathrm{H}$ NMR (DMSO- $\left.d_{6}, 200 \mathrm{MHz}\right): \delta 8.57(\mathrm{t}, J=5.4 \mathrm{~Hz}, 2 \mathrm{H}), 7.67$ $(\mathrm{s}, 2 \mathrm{H}), 7.23(\mathrm{t}, J=8.4 \mathrm{~Hz}, 2 \mathrm{H}), 7.19(\mathrm{~d}, J=7.4 \mathrm{~Hz}, 2 \mathrm{H})$, $6.97(\mathrm{~d}, J=8.4 \mathrm{~Hz}, 2 \mathrm{H}), 6.88(\mathrm{t}, J=7.4 \mathrm{~Hz}, 2 \mathrm{H}), 3.80(\mathrm{~s}$, $6 \mathrm{H}), 3.40(\mathrm{dt}, J=7.2,5.4 \mathrm{~Hz}, 4 \mathrm{H}), 2.82(\mathrm{t}, J=7.2 \mathrm{~Hz}$, $4 \mathrm{H}) .{ }^{13} \mathrm{C}$ NMR (DMSO- $\left.d_{6}, 50 \mathrm{MHz}\right): \delta 167.2,166.9,157.3$, 138.6, 133.2, 130.1, 128.3, 127.6, 127.3, 120.3, 110.7, 55.3, 40.8, 29.5. HRMS (CI+) Calculated for $\mathrm{C}_{28} \mathrm{H}_{25} \mathrm{~N}_{2} \mathrm{O}_{6}\left(\mathrm{M}-2 \mathrm{H}_{2} \mathrm{O}+1\right)$ 485.1713; Found 485.1676.

2,5-Bis(3-phenylpropylcarbamoyl)terephthalic Acid (6K). White solid. $194 \mathrm{mg}, 0.40 \mathrm{mmol}, 86 \%$. Mp 216-218 $\mathrm{C}$. FTIR: 3338, 3065, 2943, 1699, 1615, 1595, $1206 \mathrm{~cm}^{-1}$. MS (EI) $\mathrm{m} / z$ : $452\left(\mathrm{M}^{+}-2 \mathrm{H}_{2} \mathrm{O}, 25\right), 348$ (23), 244 (20), 174 (40), 117 (100), 91 (65). MS (ESI+) $m / z: 982(2 \mathrm{M}+\mathrm{Na})^{+}, 511(\mathrm{M}+\mathrm{Na})^{+}$. MS (ESI-) $m / z: 487(\mathrm{M}-\mathrm{H})^{-} \mathrm{MS} / \mathrm{MS}$ 487(4), $443(50), 399$ (100). ${ }^{1} \mathrm{H}$ NMR (DMSO- $\left.d_{6}, 200 \mathrm{MHz}\right): \delta 13.33(\mathrm{sa}, 2 \mathrm{H}), 8.53(\mathrm{t}$, $J=5.6,2 \mathrm{H}), 7.73(\mathrm{~s}, 2 \mathrm{H}), 7.31-7.18(\mathrm{~m}, 10 \mathrm{H}), 3.23(\mathrm{dt}, J=7.0$, $5.8 \mathrm{~Hz}, 4 \mathrm{H}), 2.65$ (dd, $J=8.2,7.0 \mathrm{~Hz}, 4 \mathrm{H}$ ), 1.81 (qnt, $J=7.6$, $7.0 \mathrm{~Hz}, 4 \mathrm{H}) .{ }^{13} \mathrm{C}$ NMR (DMSO- $\left.d_{6}, 50 \mathrm{MHz}\right): \delta$ 167.1, 167.0, $141.9,138.8,133.1,128.4,128.3,125.7,39.5,32.6$, 30.7. HRMS (CI+) Calculated for $\mathrm{C}_{28} \mathrm{H}_{25} \mathrm{~N}_{2} \mathrm{O}_{4}\left(\mathrm{M}-2 \mathrm{H}_{2} \mathrm{O}+1\right)$ 453.1814; Found 453.1801.

2,5-Bis(2-phenoxyethylcarbamoyl)terephthalic Acid (6L). White solid. $161 \mathrm{mg}, 0.33 \mathrm{mmol}, 71 \%$. Mp 200-202 $\mathrm{C}$. MS (ESI+) $m / z: 515(\mathrm{M}+\mathrm{H})^{+}$. MS (ESI-) $m / z: 491(\mathrm{M}-\mathrm{H})^{-}$. FTIR: 3330, 3069, 2943, 1704, 1625, 1586, $1218 \mathrm{~cm}^{-1} .{ }^{1} \mathrm{H}$ NMR (DMSO- $d_{6}, 200 \mathrm{MHz}$ ): $\delta 13.37$ (brs, $\left.2 \mathrm{H}\right), 8.78(\mathrm{t}, J=5.2 \mathrm{~Hz}$, $2 \mathrm{H}), 7.75(\mathrm{~s}, 2 \mathrm{H}), 7.29(\mathrm{t}, J=7.2 \mathrm{~Hz}, 4 \mathrm{H}), 6.95-7.00(\mathrm{~m}, 6 \mathrm{H})$, $4.10(\mathrm{t}, J=5.64 \mathrm{H}), 3.57(\mathrm{q}, J=5.2 \mathrm{~Hz}, 4 \mathrm{H}) .{ }^{13} \mathrm{C} \mathrm{NMR}$ $\left(\mathrm{DMSO} d_{6}, 50 \mathrm{MHz}\right): \delta 167.5,166.9,158.4,138.4,133.1,129.5$, 128.3, 120.6, 114.5, 65.7, 39.1. HRMS (CI+) Calculated for $\mathrm{C}_{26} \mathrm{H}_{25} \mathrm{~N}_{2} \mathrm{O}_{8}-2 \mathrm{H}_{2} \mathrm{O} 457.1400$; Found 457.1382 .
2,5-Bis(naphthalen-1-ylcarbamoyl)terephthalic Acid (6M). White solid. $194 \mathrm{mg}, 0.39 \mathrm{mmol}, 84 \%$. Mp 362-364 C. FTIR: $3242,3050,1695,1650,1524,1296 \mathrm{~cm}^{-1}$. EIMS m/z: 468 $\left(\mathrm{M}^{+}-2 \mathrm{H}_{2} \mathrm{O}, 5\right), 343$ (10), 174 (45), 143 (100), 115 (50). MS (ESI+) $m / z: 505(\mathrm{M}+\mathrm{H})^{+}$. MS (ESI-) $m / z: 503(\mathrm{M}-\mathrm{H})^{-}$ MS/MS 503 (1), 460 (10), 416 (100). ${ }^{1} \mathrm{H}$ NMR (DMSO- $d_{6}$, $200 \mathrm{MHz}$ ): $\delta 10.63(\mathrm{~s}, 2 \mathrm{H}), 8.23(\mathrm{~d}, J=7.8 \mathrm{~Hz}, 2 \mathrm{H}), 8.18$ $(\mathrm{s}, 2 \mathrm{H}), 7.98(\mathrm{dd}, J=6.0,3.0 \mathrm{~Hz}, 2 \mathrm{H}), 7.87(\mathrm{~d}, J=8.1 \mathrm{~Hz}$, $2 \mathrm{H}), 7.79$ (d, $J=7.0, \mathrm{~Hz}, 2 \mathrm{H}), 7.62-7.65(\mathrm{~m}, 6 \mathrm{H}) .{ }^{13} \mathrm{C} \mathrm{NMR}$ (DMSO- $d_{6}, 50 \mathrm{MHz}$ ): $\delta$ 167.0, 166.8, 139.4, 133.8, 133.5, 132.9, $129.3,129.2$, 128.7, 127.8, 126.4, 125.9, 123.2, 123.1, 122.5. HRMS (CI+) Calculated for $\mathrm{C}_{30} \mathrm{H}_{17} \mathrm{~N}_{2} \mathrm{O}_{4}\left(\mathrm{M}-2 \mathrm{H}_{2} \mathrm{O}+1\right)$ 469.1188; Found 469.1217.

2,5-Bis(naphthalen-1-ylmethylcarbamoyl)terephthalic Acid (6N). White solid. $240 \mathrm{mg}, 0.45 \mathrm{mmol}, 98 \%$. Mp 270-272 ${ }^{\circ} \mathrm{C}$. FTIR: $3342,3048,2916,1716,1627,1580,1567,1214 \mathrm{~cm}^{-1}$. MS (EI) $m / z: 496\left(\mathrm{M}^{+}-2 \mathrm{H}_{2} \mathrm{O}, 100\right), 248$ (10), 141 (55), 115 (30). MS (ESI+) $m / z: 555(\mathrm{M}+\mathrm{Na})^{+}$; MS (ESI-) $m / z: 531(\mathrm{M}-\mathrm{H})^{-}{ }^{1} \mathrm{H}$ NMR (DMSO- $\left.d_{6}, 400 \mathrm{MHz}\right): \delta 13.42$ (brs, 2H), 9.19 (t, $J=5.6 \mathrm{~Hz}, 2 \mathrm{H}), 8.16(\mathrm{~d}, J=8.4 \mathrm{~Hz}, 2 \mathrm{H}), 7.96(\mathrm{~d}, J=8.0 \mathrm{~Hz}$, $2 \mathrm{H}), 7.87(\mathrm{~d}, J=8.4 \mathrm{~Hz}, 2 \mathrm{H}), 7.77(\mathrm{~s}, 2 \mathrm{H}), 7.59(\mathrm{t}, J=8.4 \mathrm{~Hz}$, $4 \mathrm{H}), 7.53(\mathrm{t}, J=8.0 \mathrm{~Hz}, 2 \mathrm{H}), 7.49(\mathrm{t}, J=8.0 \mathrm{~Hz}, 2 \mathrm{H}), 4.91$ $(\mathrm{d}, J=5.6 \mathrm{~Hz}, 4 \mathrm{H}) .{ }^{13} \mathrm{C}$ NMR (DMSO- $\left.d_{6}, 50 \mathrm{MHz}\right): \delta 167.2$, 166.9, 138.4, 134.2, 133.4, 133.2, 130.9, 128.5, 127.6, 126.3, 125.8, 125.7, 125.4, 123.6, 115.7, 40.9. HRMS (CI+) Calculated for $\mathrm{C}_{32} \mathrm{H}_{21} \mathrm{~N}_{2} \mathrm{O}_{4}\left(\mathrm{M}-2 \mathrm{H}_{2} \mathrm{O}+1\right)$ 497.1501; Found 497.1513.

\section{Computational Details}

All geometry optimizations and frequency calculations were carried out with DFT method and the nonlocal correlation B3LYP with a $6-31+G(d, p)$ basis set using Gaussian 03 package in the gas-phase $[37,38]$.

\section{Conflict of Interests}

The authors declare that there is no conflict of interests regarding the publication of this paper.

\section{Acknowledgments}

The authors gratefully acknowledge the support for this project by Dirección General de Educación Superior Tecnológica, México (DGEST-2009, Grant no. 2539.09-P) and by Programa de Mejoramiento del Profesorado, México (PROMEP, Grant. no. ITTIJ-001).

\section{References}

[1] G. F. Katekar and A. E. Geissler, "Auxin transport inhibitors: IV. Evidence of a common mode of action for a proposed class of auxin transport inhibitors: the phytotropins," Plant Physiology, vol. 66, no. 6, pp. 1190-1195, 1980.

[2] G. F. Katekar, J.-F. Navé, and A. E. Geissler, "Phytotropins: III. Naphthylphthalamic acid binding sites on maize coleoptile 
membranes as possible receptor sites for phytotropin action," Plant Physiology, vol. 68, no. 6, pp. 1460-1464, 1981.

[3] J. G. Voet, K. S. Howley, and J. S. Shumsky, " 5 '-Azido$\mathrm{N}$-1-Napthylphthalamic acid, a photolabile analog of $\mathrm{N}-1-$ Naphthylphthalamic acid : synthesis and binding properties in curcurbita pepo L," Plant Physiology, vol. 85, no. 1, pp. 22-25, 1987.

[4] C. Wu, R. Dickstein, A. J. Cary, and J. H. Norris, "The auxin transport inhibitor N-(1-naphthyl)phthalamic acid elicits pseudonodules on nonnodulating mutants of white sweetclover," Plant Physiology, vol. 110, no. 2, pp. 501-510, 1996.

[5] V. L. M. Sena, R. M. Srivastava, S. P. Oliveira, and V. L. M. Lima, "Microwave assisted synthesis of $N$-Arylphthalamic acids with hyperlipidemic activity," Bioorganic \& Medicinal Chemistry Letters, vol. 11, no. 20, pp. 2671-2674, 2001.

[6] V. L. M. Sena, R. M. Srivastava, R. O. Silva, and V. L. M. Lima, "Synthesis and hypolipidemic activity of $N$-substituted phthalimides. Part V,' Il Farmaco, vol. 58, no. 12, pp. 1283-1288, 2003.

[7] J. Leban, B. Kramer, W. Saeb, and G. Garcia, "Novel compounds as anti-inflammatory, immunomodulatory and anti-proliferatory agents," US Patent no. US 20060199856, 2006.

[8] W. J. Ries, H. Priepke, H. Nar, J.-M. Stassen, and W. Wienen, "Carboxylic acid amides having antithrombotic activity," US Patent no. US20020151595 A, 2002.

[9] K. H. Mayer, H.-J. Kabbe, and H. Otten, "Benzoic acid amides for mycobacterium infections," US Patent no. 4006239, 1977.

[10] F. G. Bollinger and J. J. D' Amico, "Use of pyridyl phthalamic acids as plant growth regulants," US Patent no. 4,086,078, 1978.

[11] V. M. Balaramnavar, I. A. Khan, J. A. Siddiqui et al., "Identification of novel 2-((1-(Benzyl(2-hydroxy-2-phenylethyl)amino)-1oxo-3-phenylpropan-2-yl)carbamoyl)benzoic acid analogues as BMP-2 stimulators," Journal of Medicinal Chemistry, vol. 55, no. 19, pp. 8248-8259, 2012.

[12] J. M. Goze, R. J. Bernhardt, B. Sajic, N. M. Rockwell, and W. R. Mohring, "N,N-disubstituted phthalamic acids and their ammonium salts, and their uses thereof as surfactants, emulsifiers, and conditioning agents in shampoos," US Patent no. $5,015,415,1991$.

[13] I. Shapiro and B. Sajic, "Antiperspirant formulations," US Patent No. 5,188,823, 1993.

[14] V. Ravindar, S. J. Swamy, S. Srihari, and P. Lingaiah, "Synthesis and spectral studies of copper(II) complexes with amide group ligands," Polyhedron, vol. 4, no. 8, pp. 1511-1518, 1985.

[15] E. F. Hoegger, "Direct preparation of aromatic polyimides," US Patent no. 3342774, 1967.

[16] M. Fryd and D. L. Goff, "Process for making photopolymerizable aromatic polyamic acid derivatives," US Patent no. 4,551,522, 1985.

[17] A. K. St. Clair and T. L. St. Clair, "Process for preparing highly optically transparent/colorless aromatic polyimide film," US Patent no. 4603061, 1986.

[18] C.-M. Leu, H.-L. Tyan, and T.-M. Lee, "Liquid crystal display device," US Patent no. 7727600, 2010.

[19] N. H. You, Y. Suzuki, D. Yorifuji, S. Ando, and M. Ueda, "Synthesis of high refractive index polyimides derived from 1,6-Bis( $p$-aminophenylsulfanyl)-3,4,8,9-tetrahydro-2,5,7,10-tetrathiaanthracene and aromatic dianhydrides," Macromolecules, vol. 41, no. 17, pp. 6361-6366, 2008.

[20] M. Calle, A. E. Lozano, J. G. De La Campa, and J. De Abajo, "Novel aromatic polyimides derived from 5 '- $t$ Butyl-2' - pivaloylimino-3,4,3", $4^{\prime \prime}-m$-terphenyltetracarboxylic dianhydride with potential application on gas separation processes," Macromolecules, vol. 43, no. 5, pp. 2268-2275, 2010.

[21] S. Mallakpour and M. Dinari, "High performance polymers in ionic liquid: a review on prospects for green polymer chemistry. Part II: polyimides and polyesters," Iranian Polymer Journal, vol. 20, no. 4, pp. 259-279, 2011.

[22] P. M. Hergenrother, "The use, design, synthesis, and properties of high performance/high temperature polymers: an overview," High Performance Polymers, vol. 15, no. 1, pp. 3-45, 2003.

[23] C. Feger, M. M. Khojasteh, and M. S. Htoo, Advances in Polyimide Science and Technology, Technomic, Lancaster, Pa, USA, 1993.

[24] M. J. M. Abadie and B. Sillion, Polyimides and other HighTemperature Polymers, Elsevier, Amsterdam, The Netherlands, 1991.

[25] K. L. Mittal, Polyimides: Synthesis, Characterization and Application, vol. 1, Plenum, New York, NY, USA, 1984.

[26] J. E. Rogers and L. A. Kelly, "Nucleic acid oxidation mediated by naphthalene and benzophenone imide and diimide derivatives: consequences for DNA redox chemistry," Journal of the American Chemical Society, vol. 121, no. 16, pp. 3854-3861, 1999.

[27] G. Kaiser, T. Jarroson, S. Otto, Y.-F. Ng, A. D. Bond, and J. K. M. Sanders, "Lithium-templated synthesis of a donor-acceptor pseudorotaxane and catenane," Angewandte Chemie, vol. 43, no. 15, pp. 1959-1962, 2004.

[28] S. V. Bhosale, C. H. Jani, and S. J. Langford, "Chemistry of naphthalene diimides," Chemical Society Reviews, vol. 37, pp. 331-342, 2008.

[29] Y.-L. Lee, H.-L. Hsu, S.-Y. Chen, and T.-R. Yew, "Solutionprocessed naphthalene diimide derivatives as n-type semiconductor materials," The Journal of Physical Chemistry C, vol. 112, no. 5, pp. 1694-1699, 2008.

[30] K. Tambara, N. Ponnuswamy, G. Hennrich, and G. Dan Pantos, "Microwave-assisted synthesis of naphthalenemonoimides and N-desymmetrized naphthalenediimides," The Journal of Organic Chemistry, vol. 76, no. 9, pp. 3338-3347, 2011.

[31] M. Prorok, S. E. Warder, T. Blandl, and F. J. Castellino, "Calcium binding properties of synthetic $\gamma$-carboxyglutamic acidcontaining marine cone snail "Sleeper" peptides, conantokinG and conantokin-T,' Biochemistry, vol. 35, no. 51, pp. 1652816534, 1996.

[32] M. Hu, Y. Ishizuka, Y. Igarashi, T. Oki, and H. Nakanishi, "NMR study of pradimicin derivative BMY-28864 and its interaction with calcium ions in $\mathrm{D}_{2} \mathrm{O}$," Spectrochimica Acta-Part A, vol. 55, no. 12, pp. 2547-2558, 1999.

[33] H. Santacruz, R. E. Navarro, L. Machi, R. Sugich-Miranda, and $\mathrm{M}$. Inoue, "Solution structures of fluorescent $\mathrm{Zn}$ (II) complexes with bis(naphthyl amide)-EDTA," Polyhedron, vol. 30, no. 5, pp. 690-696, 2011.

[34] M. P. Williamson, "Using chemical shift perturbation to characterise ligand binding," Progress in Nuclear Magnetic Resonance Spectroscopy, vol. 73, pp. 1-16, 2013.

[35] W. Yang and W. J. Mortier, "The use of global and local molecular parameters for the analysis of the gas-phase basicity of amines," Journal of the American Chemical Society, vol. 108, no. 19 , pp. $5708-5711,1986$.

[36] L. E. Gómez-Pineda, G. E. Pina-Luis, C. M. Cortés-Romero et al., "Quantum chemical calculations on the interaction between flavonol and functional monomers (methacrylic acid and 4vinylpyridine) in molecularly imprinted polymers," Molecules, vol. 15, no. 6, pp. 4017-4032, 2010. 
[37] C. Lee, W. Yang, and R. G. Parr, "Development of the ColleSalvetti correlation-energy formula into a functional of the electron density," Physical Review B, vol. 37, no. 2, pp. 785-789, 1988.

[38] M. J. Frisch, G. W. Trucks, H. B. Schlegel et al., "Gaussian 03, revision C.02," Gaussian, Wallingford, Conn, USA, 2004. 

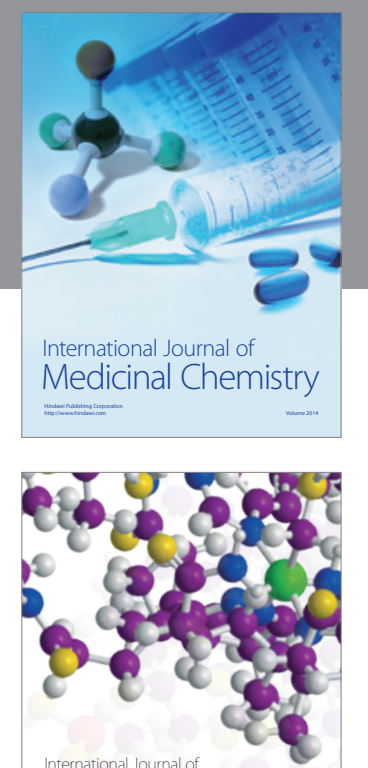

\section{Carbohydrate} Chemistry

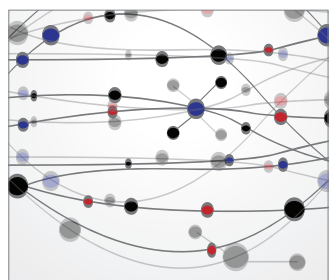

The Scientific World Journal
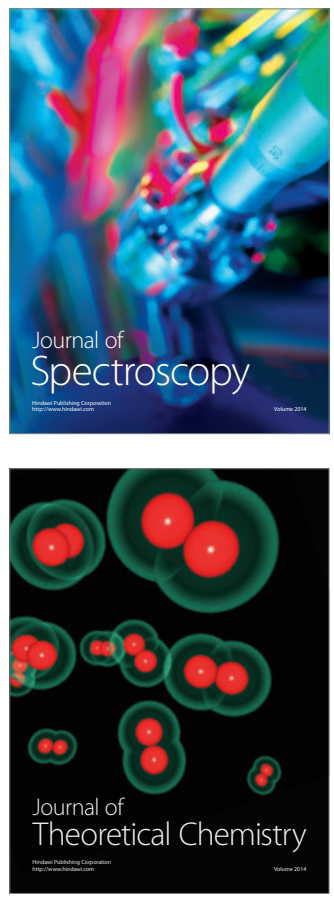
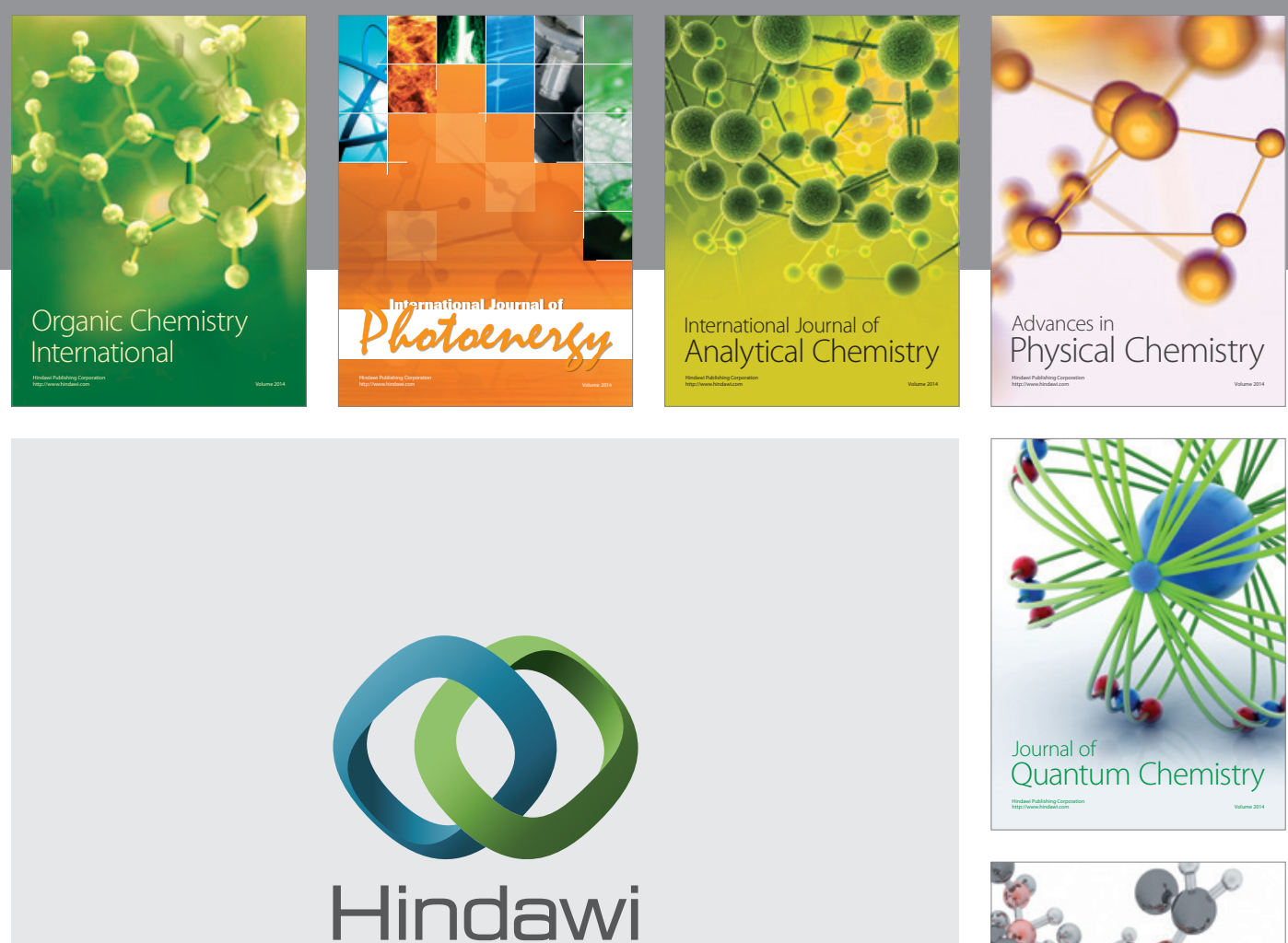

Submit your manuscripts at

http://www.hindawi.com

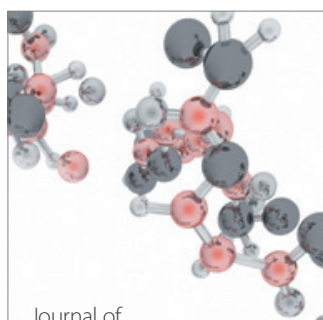

Analytical Methods

in Chemistry

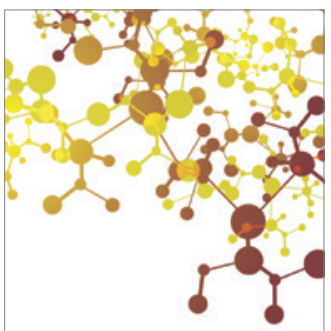

Journal of

Applied Chemistry

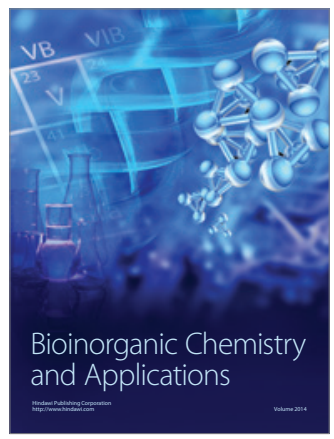

Inorganic Chemistry
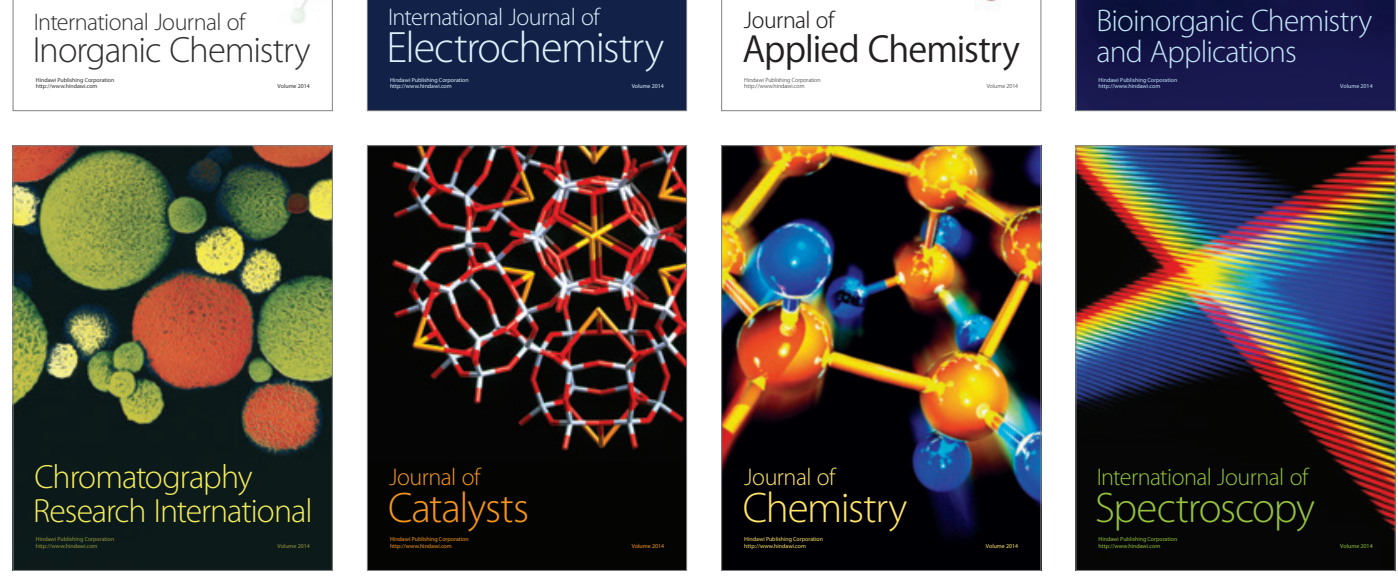